\title{
The water column of the Yamal tundra lakes as a microbial filter preventing methane emission
}

\author{
Alexander Savvichev ${ }^{1}$, Igor Rusanov ${ }^{1}$, Yury Dvornikov ${ }^{2}$, Vitaly Kadnikov $^{1}$, Anna Kallistova $^{1}$, Elena Veslopolova ${ }^{1}$, \\ Antonina Chetverova ${ }^{3,4}$, Marina Leibman ${ }^{5}$, Pavel A. Sigalevich ${ }^{1}$, Nikolay Pimenov ${ }^{1}$, Nikolai Ravin ${ }^{1}$, and \\ Artem Khomutov ${ }^{5}$ \\ ${ }^{1}$ Winogradsky Institute of Microbiology and Institute of Bioengineering, Research Centre of Biotechnology \\ of the Russian Academy of Sciences, 119071, Moscow, Russia \\ ${ }^{2}$ Department of Landscape Design and Sustainable Ecosystems, Agrarian and Technological Institute, RUDN University, \\ Miklukho-Maklaya Str. 6, 117198, Moscow, Russia \\ ${ }^{3}$ Institute of Earth Sciences, Saint Petersburg University, 199034, Saint Petersburg, Russia \\ ${ }^{4}$ Otto Schmidt Laboratory for Polar and Marine Research, Arctic and Antarctic Research Institute, \\ 199397, Saint Petersburg, Russia \\ ${ }^{5}$ Earth Cryosphere Institute of Tyumen Scientific Centre, Siberian Branch, Russian Academy of Sciences, \\ 625000, Tyumen, Russia
}

Correspondence: Pavel A. Sigalevich (pavelsigalevich@list.ru)

Received: 22 August 2020 - Discussion started: 30 October 2020

Revised: 12 March 2021 - Accepted: 19 March 2021 - Published: 5 May 2021

\begin{abstract}
Microbiological, molecular ecological, biogeochemical, and isotope geochemical research was carried out in four lakes of the central part of the Yamal Peninsula in the area of continuous permafrost. Two of them were large (73.6 and 118.6 ha) and deep (up to 10.6 and $12.3 \mathrm{~m}$ ) mature lakes embedded into all geomorphological levels of the peninsula, and two others were smaller ( 3.2 and 4.2 ha) shallow $(2.3$ and $1.8 \mathrm{~m})$ lakes which were formed as a result of thermokarst on constitutional (segregated) ground ice. Samples were collected in August 2019. The Yamal tundra lakes were found to exhibit high phytoplankton production (340-1200 $\mathrm{mg} \mathrm{C} \mathrm{m}^{-2} \mathrm{~d}^{-1}$ ) during the short summer season. Allochthonous and autochthonous, particulate and dissolved organic matter was deposited onto the bottom sediments, where methane was the main product of anaerobic degradation, and its content was 33-990 $\mu \mathrm{mol} \mathrm{CH}_{4} \mathrm{dm}^{-3}$. The rates of hydrogenotrophic methanogenesis appeared to be higher in the sediments of deep lakes than in those of the shallow ones. In the sediments of all lakes, Methanoregula and Methanosaeta were predominant components of the archaeal methanogenic community. Methane oxidation $\left(1.4-9.9 \mu \mathrm{mol} \mathrm{dm}^{-3} \mathrm{~d}^{-1}\right)$ occurred in the upper sediment layers simultaneously
\end{abstract}

with methanogenesis. Methylobacter tundripaludum (family Methylococcaceae) predominated in the methanotrophic community of the sediments and the water column. The activity of methanotrophic bacteria in deep mature lakes resulted in a decrease in the dissolved methane concentration in lake water from $0.8-4.1$ to $0.4 \mu \mathrm{mol} \mathrm{CH}_{4} \mathrm{~L}^{-1} \mathrm{~d}^{-1}$, while in shallow thermokarst lakes the geochemical effect of methanotrophs was much less pronounced. Thus, only small, shallow Yamal lakes may contribute significantly to the overall diffusive methane emissions from the water surface during the warm summer season. The water column of large, deep lakes on Yamal acts, however, as a microbial filter preventing methane emission into the atmosphere. It can be assumed that climate warming will lead to an increase in the total area of thermokarst lakes, which will enhance the effect of methane release into the atmosphere.

\section{Introduction}

Climate warming, recorded on the Earth in recent decades, is especially pronounced at high latitudes of the Northern Hemisphere (IPCC, 2014). As a result, ground temperatures 
of the permafrost-covered area undergo a consistent rise (Biskaborn et al., 2019). The Yamal Peninsula is a remarkable area characterized by active cryogenic relief-forming processes (Kizyakov and Leibman, 2016) and many water bodies. The limnicity of Yamal varies between 10 and $20 \%$, depending on the position at the geomorphological level, with the maximum observed on floodplains (Romanenko, 1999). These lakes have been classified as thermokarst lakes in continuous ice-rich permafrost (Dubikov, 1982), although other origins have also been proposed (Arctic and Antarctic Research Institute, 1977; Kritsuk, 2010). Thermokarst lakes originate from the thawing of ice-rich permafrost or pure ice of various genesis (Kachurin, 1961). This thawing process results in topographic depressions that are immediately filled with water in flat areas (Romanovskii, 1993). Thermokarst lakes are widespread in West and East Siberia, in Alaska and northern Canada, the Hudson Bay Lowlands, and northern Scandinavia (Marsh et al., 2009; Grosse et al., 2013; Kravtsova and Rodionova, 2016; Vonk et al., 2015; Wik et al., 2016). The depth of these lakes is highly dependent on the type of ground ice beneath. Shallow lakes may result from the thaw of segregated ice with lower ice content (Dostovalov and Kudryavtsev, 1967), e.g., tabular ground ice widespread in the north of West Siberia. These lakes are generally shallow $(<3.0 \mathrm{~m})$ and range in size from a few square meters to hundreds of square kilometers (Grosse et al., 2013; Wik et al., 2016).

For the area of continuous permafrost in West Siberia, an increase in total lake area by $12 \%$ has been observed in recent decades due to climate warming (Smith et al., 2005). Although small thermokarst lakes were found to be more active greenhouse gas emitters than large lakes, their contribution to the total diffusive greenhouse gas emissions for the entire West Siberian Lowland is considered to be minor, less than 1\%-1.5\% (Polishchuk et al., 2018). Nonetheless, the rates of diffuse methane emission from some thermokarst lakes are rather high, exceeding the emission from terrestrial tundra ecosystems (Wik et al., 2016). The amount of methane emitted to the atmosphere is expected to be increasing due to the permafrost thawing (Heslop et al., 2015; Laurion et al., 2010; Martinez-Cruz et al., 2015; Pokrovskiy et al., 2012; Serikova et al., 2019; Townsend-Small et al., 2017; Vonk et al., 2015; Walter Anthony et al., 2007; Wik et al., 2016). Permafrost thawing results in an inflow of biogenic elements as components of mineral and organic matter $(\mathrm{OM})$ into freshwater lakes (thermokarst, floodplain, gas-emission craters, GECs, etc.) (Dvornikov et al., 2018; Vonk et al., 2015). In summer, mineral compounds stimulate phytoplankton development (blooms) in the photic layer of the water column (Edelstein et al., 2017). Cyanobacterial bloom results in the formation of autochthonous OM (primary production) (Patova, 2014). The newly formed OM acts as an easily consumable trophic resource for heterotrophic bacterioplankton. Autochthonous and allochthonous OM forms a suspension in water which subsequently precipitates forming the bottom sediments. OM degradation in the sediments occurs as a result of activity of a psychrophilic microbial community. Since sulfate concentration in Yamal lakes is rather low (Fotiev, 1999), sulfate reduction is not intense, and methane produced by methanogenic archaea is the main product of $\mathrm{OM}$ mineralization (Sepulveda-Jauregui et al., 2015; Vonk et al., 2015; Walter Anthony et al., 2006). Data on methane emission from different types of lakes, as well as on the ratio between modern microbially produced methane and the methane from thawing permafrost, are important for the understanding of the methane cycle in this area. Methane is actively consumed by methanotrophic microorganisms under both oxic and anoxic conditions. Methanotrophs play a key role in the methane cycle; they oxidize methane, thus decreasing its emission into the atmosphere. Methane, whether it is released from thawing permafrost deposits or produced in the sediments by methanogenic archaea, arrives into the water column. In the lakes located in the permafrost area, methanotrophs consume up to $60 \%$ of total methane (Singleton et al., 2018; Xu et al., 2016). The highest rates of methane oxidation usually occur in the top layer of the sediments where $\mathrm{CH}_{4}$ and $\mathrm{O}_{2}$ form steep counter gradients (Auman et al., 2000). Hence, by mitigating $\mathrm{CH}_{4}$ emissions, microorganisms act as an efficient microbial $\mathrm{CH}_{4}$ filter (Bastviken et al., 2004; Cole et al., 1994).

The carbon isotope composition of methane $\left(\delta^{13} \mathrm{C}\right)$ varies depending on its origin (Sassen and Macdonald, 1997). In the course of oxidation by methanotrophic bacteria, methane containing the light carbon isotope is preferentially consumed (Colin Murrell and Jetten, 2009; Hamdan et al., 2011). Methane carbon enriched with the light ${ }^{12} \mathrm{C}$ isotope is converted to $\mathrm{CO}_{2}$ and organic compounds in the cells of methanotrophs. As a result, OM of methanotrophic origin enriches suspended organic matter with the light carbon isotope, while methane unconsumed by methanotrophs becomes enriched with the heavy carbon isotope. Thus, the data on methane carbon isotope composition indicate the geochemical consequences of microbial processes of the methane cycle (Heuer et al., 2009).

In Yamal, large, deep lakes are common, especially on floodplains of rivers (such as Mordyyakha and Seyakha). Their basins are highly developed, and it can be considered that the thermokarst is presently not the main process involved in the formation of such lake basins. One more mechanism responsible for the emergence of new lakes in Yamal is the formation of gas-emission craters. Recent studies related to these permafrost features (Leibman et al., 2014) showed that initially deep (20-50 m) craters rapidly (within three to four summer seasons) turned into shallow (3-5 m) lakes by the filling of the craters with thawed tabular ground ice and atmospheric precipitation (Dvornikov et al., 2019). These newly formed lakes become very similar to other lakes in Yamal in terms of their morphometry and hydrochemistry. Winter studies revealed lower methane 
production in the sediments of young lakes filling the gasemission craters than in the sediments of mature tundra lakes (Savvichev et al., 2018a).

The present work was aimed at the microbiological and biogeochemical characterization of the carbon turnover in Central Yamal's small young lakes (constitutional ice thermokarst) and deep mature lakes (massive ground ice thermokarst) with a focus on the methane cycle processes. For this purpose, the investigation of the following parameters was required: (1) primary production, (2) dark $\mathrm{CO}_{2}$ assimilation, (3) the rate of hydrogenotrophic methanogenesis, (4) the rate of methane oxidation, and (5) abundance and composition of microbial communities in the water column.

\section{Sampling site and analytical methods}

\subsection{Study site}

In this work, four basins were under study: two typical shallow thermokarst lakes and two large and deep lakes located in the vicinity of Vas'kiny Dachi research station in Central Yamal (Fig. 1) within the framework of the longterm monitoring program of the Earth Cryosphere Institute (Dvornikov et al., 2016). All studied lakes are located in the area of continuous permafrost with an average ground temperature of up to $-7^{\circ} \mathrm{C}$ at the level of zero annual amplitudes and with the active layer depth varying between 0.5 and $1.3 \mathrm{~m}$. The permafrost is characterized by high ice content (Dubikov, 1982). The morphometric characteristics of the studied lakes are summarized in Table 1.

The basins in the study area were mostly freshwater lakes. The predominant anion was $\mathrm{Cl}^{-}(56.7 \mathrm{eq} \%$ on average among $\sim 30$ lakes), with the proportion of anions in the following order: $\mathrm{Cl}^{-}>\mathrm{HCO}_{3}^{-}>\mathrm{SO}_{4}^{2-}$. Cations were strongly dominated by $\mathrm{Na}^{+}+\mathrm{K}^{+}(58.5 \mathrm{eq} \%$ on average). The proportion of cations was in the following order: $\mathrm{Na}^{+}+\mathrm{K}^{+}>\mathrm{Mg}^{2+}>\mathrm{Ca}^{2+}$. The total mineralization in lakes was normally below $150 \mathrm{mg} \mathrm{L}^{-1}$ (Dvornikov et al., 2019). Lakes LK-002 and LK-010 are small in area, with the depth not exceeding $2.3 \mathrm{~m}$ (Table 1). During winter, most of the area of these lakes is frozen to the bottom. For microbial processes in these lakes, the absence of the water column stratification during the short summer season is an important factor. Thus, in deep lakes the temperatures of the surface and near-bottom layers were $15.1-15.8$ and $12.0-14.2^{\circ} \mathrm{C}$, respectively (Table 1). Strong winds, low coasts, and the absence of the pycnocline provided for efficient mixing of the water column. In-depth analysis of the absence of stratification in the water column of Yamal lakes has been provided elsewhere (Dvornikov et al., 2019). Their bottom sediments have a high content of undecomposed organic matter. Lakes LK-003 and LK-004 are large and deep and had well-developed basins with sandy bottoms. According to their basic morphometric characteristics, we suggested lakes LK-002 and LK-010 to be the young, developing lakes of thermokarst origin, while lakes LK-003 and LK-004 were mature and of debatable origin.

\subsection{Sample collection and characterization}

Water and surface sediment samples were collected from four lakes during the period from 5 August till 9 August 2019. Water samples were collected from the entire water column at the deepest parts of the lake (Table 1). A total of 13 water samples were collected (Table 1). Water was sampled using a TD-Automatika $\odot$ hydrological water sampler, dispensed into $35 \mathrm{~mL}$ glass vials, sealed with gastight rubber stoppers (avoiding gas bubbles), and covered with a perforated aluminum cap.

Bottom sediments (with a core length of up to $340 \mathrm{~mm}$ ) were collected using a limnological stratometer with a glass tube. A total of 12 sediment samples were collected: LK$003,0-3,3-7$, and 3-12 cm; LK-004, 0-4, 4-9, and 9$15 \mathrm{~cm}$; LK-002, 0-4, 4-9, and 9-14 cm; and LK-010, 0-3, $3-6$, and $6-12 \mathrm{~cm}$. The thawed ground ice flowing into the lake was collected at the lower part of lake LK-004's slope (sample LK-004K). Sediment samples were then transferred into cut-off $5 \mathrm{~mL}$ plastic syringes, preserving the structure of the sediment core, and sealed with gas-tight rubber stoppers so that contact of the samples with air was avoided. The procedure has been described elsewhere (Pimenov and Bonch-Osmolovskaya, 2006). Samples of water and sediments were stored in a portable temperature-controlled box at +8 to $+12^{\circ} \mathrm{C}$. Pore water from sediment samples was obtained by centrifugation at $8000 \mathrm{~g}$ for $10 \mathrm{~min}$ in a TsUM-1 centrifuge (Russia). The temperature, electrical conductivity (EC), and concentration of dissolved oxygen were measured using a WTW 3320 SET2 portable multimeter (Germany) equipped with a CellOx-325 dissolved oxygen detector and a TetraCon 325 conductometer.

\subsection{Analytical techniques}

Methane content in the water and sediment samples was determined using the head-space method (McAuliffe, 1971). Methane concentration was measured on a Kristall-2000M gas chromatograph (Chromatec, Russia) equipped with a flame ionization detector. The concentrations of sulfate and chloride ions were determined (after distillation and concentration) on a Staier ion chromatograph (Akvilon, Russia). Carbon content in dissolved organic matter (DOC) was determined by high-temperature incineration (nonpurgeable organic carbon, NPOC) using a Shimadzu TOC$\mathrm{VCPH}$ analyzer (Japan) with a measurement accuracy of $\pm 10 \%$. Average values were calculated from three samples. Statistical treatment of the results was performed using Excel 2000. 

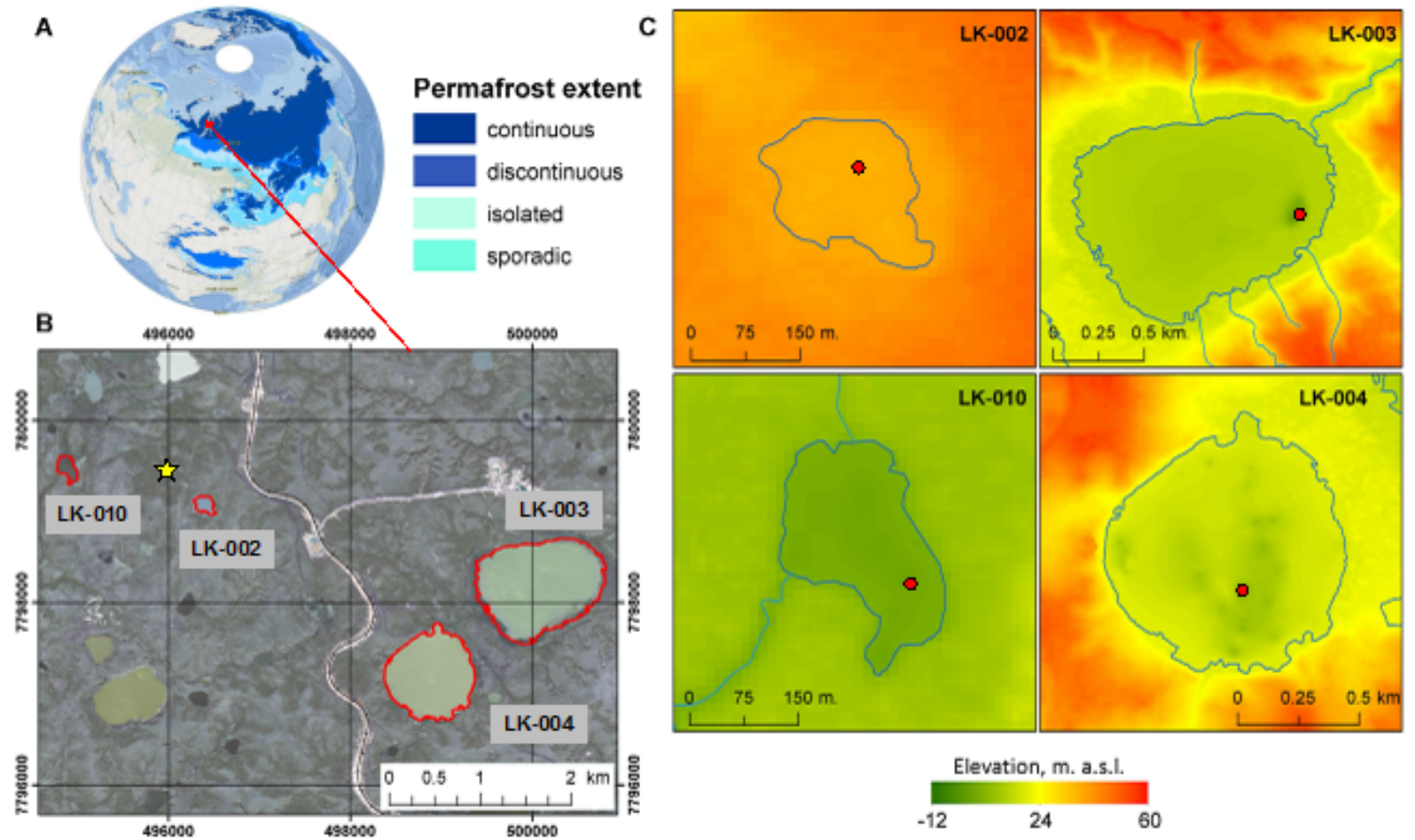

Figure 1. (a) An overview map of Eurasia with permafrost extent from Brown et al. (2002). (b) Study area map of Central Yamal. Redoutlined polygons indicate the lakes under study, and the yellow star indicates Vas'kiny Dachi research station. The orthorectified QuickBird satellite image acquired on 30 July 2010 was used as a background (source: Digital Globe Foundation@): datum - WGS-84; projection UTM Zone 42 N. (c) Topography of the lake basins under study: red dots indicate the sites of the water and sediment sampling, and elevations are given in the Baltic height system (1977).

Table 1. Characteristics of Yamal lakes: morphometry, hydrological, and hydrochemical parameters.

\begin{tabular}{|c|c|c|c|c|c|c|c|c|c|}
\hline \multirow[t]{2}{*}{$\begin{array}{l}\text { Lake ID } \\
\text { (max depth, } \\
\text { m) }\end{array}$} & \multirow[t]{2}{*}{$\begin{array}{l}\text { Type, } \\
\text { aging of } \\
\text { lakes }\end{array}$} & \multirow[t]{2}{*}{$\begin{array}{l}\text { Basin } \\
\text { embedded } \\
\text { into }\end{array}$} & \multirow[t]{2}{*}{$\begin{array}{r}\text { Area } \\
\text { (ha) }\end{array}$} & \multirow[t]{2}{*}{$\begin{array}{r}\text { Coordinates, } \\
\text { (NL WL) }\end{array}$} & $\begin{array}{r}\text { EC } \\
\left(\mu \mathrm{S} \mathrm{cm}^{-1}\right)\end{array}$ & $\begin{array}{r}\mathrm{O}_{2} \\
\left(\mathrm{mg} \mathrm{L}^{-1}\right)\end{array}$ & $\begin{array}{r}T \\
\left({ }^{\circ} \mathrm{C}\right)\end{array}$ & \multirow[t]{2}{*}{$\begin{array}{r}\text { Secchi } \\
\text { depths } \\
\text { (m) }\end{array}$} & \multirow[t]{2}{*}{$\begin{array}{r}\text { Sampling } \\
\text { depths } \\
(\mathrm{m})\end{array}$} \\
\hline & & & & & \multicolumn{3}{|c|}{ Surface water (near-bottom water) } & & \\
\hline LK-010 (1.2) & Modern & Floodplain & 4.25 & 70.301268 .8642 & 269 & 9.4 & 14.4 & 0.90 & $0 ; 1.1$ \\
\hline LK-002 (2.0) & Modern & Coastal-marine plain & 3.23 & 70.297768 .9045 & 118 & 9.8 & 11.7 & 0.75 & $0 ; 0.9 ; 1.9$ \\
\hline LK-003 (10.6) & Mature & Marine plain & 118.6 & 70.289869 .0019 & $123(124)$ & $10.0(8.6)$ & $15.8(12.0)$ & 1.20 & $0 ; 2.5 ; 7.0 ; 10.0$ \\
\hline LK-004 (11.5) & Mature & Marine plain & 73.6 & 70.280968 .9705 & $115(116)$ & $9.7(8.6)$ & $15.1(14.2)$ & 1.00 & $0 ; 3.0 ; 11.0$ \\
\hline
\end{tabular}

\subsection{Bacterial abundance}

For assessment of total microbial abundance (MA) and microbial biomass, water samples in glass vials were fixed with glutaraldehyde at the final concentration of $2 \%$. Fixed samples $(5-10 \mathrm{~mL})$ were filtered through black polycarbonate $0.2 \mu \mathrm{m}$ filters (Millipore, USA). The filters were stained with acridine orange $\left(2 \mathrm{mg} \mathrm{mL}^{-1}\right)$ (Hobbie et al., 1977) and examined under an Olympus BX 41 epifluorescence microscope equipped with an ImageScopeColor $\mathrm{M}$ visualization system. Cell volumes of the cocci and rods were calculated by approximating them as geometric spheres and cylinders, respectively. The cells were enumerated in
20 fields of view. Biomass was calculated using the data on the volume of microbial cells and assuming $1.0 \mathrm{mg} \mathrm{mm}^{-3}$ as the density of wet biomass. Specific biomass of microbial cells $(B)$ is therefore presented in micrograms per liter $\left(\mu \mathrm{g} \mathrm{L}^{-1}\right)$. During microscopic examination of the stained preparations, single cells and cells associated with aggregates were enumerated separately. A group of cells with a common outline, in which the visual enumeration of individual cells was difficult or impossible, was considered an aggregate.

\subsection{Radiotracer experiments}

The rates of microbial processes - light and dark $\mathrm{CO}_{2}$ assimilation (LCA and DCA), autotrophic (hydrogenotrophic) 
methanogenesis (MG-h), and methane oxidation (MO) - were determined using radiotracer labeled compounds $\left(\mathrm{NaH}^{14} \mathrm{CO}_{3}\right.$, specific activity $2.04 \mathrm{GBq} \mathrm{mmol}^{-1}$, Amersham, UK; $10 \mu \mathrm{Ci}$ per sample and ${ }^{14} \mathrm{CH}_{4}$, specific activity $1.16 \mathrm{GBq} \mathrm{mmol}^{-1}$, JSC Isotope, Russia; $1 \mu \mathrm{Ci}$ per sample). To determine the LCA and DCA rates, two transparent vials and one darkened vial were used for each sampling horizon. Each transparent vial was covered with an individual sheath calibrated for the transmission of the photosynthetically active radiation corresponding to the illumination in the sampling horizon. A labeled substrate $(0.2 \mathrm{~mL}$ as a sterile degassed water solution) was injected through the rubber stopper with a syringe. The vials were incubated for half the daylight period at in situ temperature. After incubation, they were fixed with $1 \mathrm{~mL} 0.1 \mathrm{~N} \mathrm{HCl}$ and filtered through $0.2 \mu \mathrm{m}$ nylon membranes. Photosynthetic production was calculated as the difference between the values for the dark and transparent vials. Incubation of water and sediment samples to determine the rates of other processes (MG-h and MO) was also carried out in situ. These processes (MG-h and MO) were stopped by injecting $0.5 \mathrm{~mL}$ of saturated $\mathrm{KOH}$ solution into each experimental vial (water samples) and plastic syringe (sediment samples). All experiments were performed in duplicate. After the end of the experiments, the vials were stored at $5-10{ }^{\circ} \mathrm{C}$. The measurement of radioactivity of the products of microbial activity in both the experimental and control vials was performed in the laboratory as described earlier (Pimenov and Bonch-Osmolovskaya, 2006; Savvichev et al., 2018b). Radioactivity was measured on a TRI-Carb TR 2400 scintillation counter (Packard, USA). The calculation of the LCA and DCA rates was done considering the ${ }^{14} \mathrm{C}-\mathrm{CO}_{2}$ both in bacterial cells and in the extracellular dissolved organic matter. For the calculation of MO rates, ${ }^{14} \mathrm{C}_{-} \mathrm{CH}_{4}$ conversion to $\mathrm{CO}_{2}$, biomass, and extracellular soluble $\mathrm{OM}$ were analyzed separately. The confidence interval for the LCA, DCA, MG-h, and MO rates varied from $10 \%-40 \%$.

\subsection{Isotopic composition of methane carbon}

The $\delta^{13} \mathrm{C}$ methane value was determined on a TRACE GC (gas chromatograph; Thermo Fisher Scientific, USA) coupled with a DELTA Plus mass spectrometer (Thermo Electron Corporation, Langenselbold, Germany) using a PDB-calibrated (PDB stands for Pee Dee Belemnite) standard and calculated according to the following equation:

${ }^{13} \mathrm{C}=\left(\left(\left[{ }^{13} \mathrm{C}\right] /\left[{ }^{12} \mathrm{C}\right]\right)_{\text {sample }} /\left(\left[{ }^{13} \mathrm{C}\right] /\left[{ }^{12} \mathrm{C}\right]\right)_{\text {standard }}-1\right) \times 1000 \%$,

where $\left(\left[{ }^{13} \mathrm{C}\right] /\left[{ }^{12} \mathrm{C}\right]\right)$ sample / $\left(\left[{ }^{13} \mathrm{C}\right] /\left[{ }^{12} \mathrm{C}\right]\right)$ standard are the ratios of occurrence of the ${ }^{12} \mathrm{C}$ and ${ }^{13} \mathrm{C}$ atoms in the sample and in the standard, respectively. The international PDB standard used has the isotope occurrence ratio $\left[{ }^{13} \mathrm{C}\right] /\left[{ }^{12} \mathrm{C}\right]$ of 0.001172 (Craig, 1957). The error of the $\delta^{13} \mathrm{C}$ measurements did not exceed $\pm 0.1 \%$.

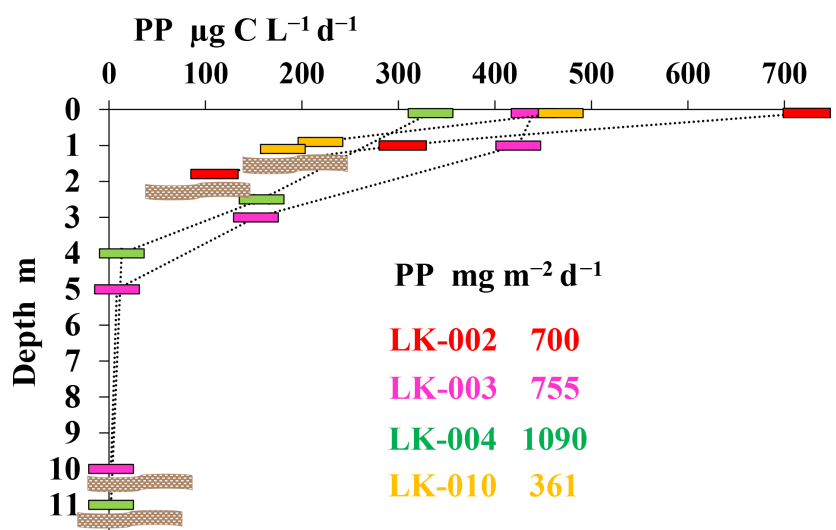

Figure 2. Primary production (PP) in four lakes of the Yamal Peninsula (August 2019) in the water horizons $\left(\mu \mathrm{g} \mathrm{CL}^{-1} \mathrm{~d}^{-1}\right)$ and integral PP for the entire water column $\left(\mathrm{mg} \mathrm{C} \mathrm{m}^{-2} \mathrm{~d}^{-1}\right)$. For all stations, location of the bottom is indicated by a brown wavy band.

\subsection{DNA extraction and sequencing procedure}

To collect microbial biomass, the water sample $(500 \mathrm{~mL})$ was passed through filters with a pore diameter of $0.22 \mu \mathrm{m}$. The filters were homogenized by triturating with liquid nitrogen, and the preparation of metagenomic DNA was isolated using the DNeasy PowerSoil Kit (Qiagen, Hilden, Germany) according to the manufacturer's instructions. The total amount of isolated DNA was about $0.5 \mu \mathrm{g}$ per sample. The V3-V4 variable region of the prokaryotic 16S rRNA genes was obtained by polymerase chain reaction (PCR) with the primers 341F (5'-CCTAYGGGDBGCWSCAG) and 806R (5'-GGACTACNVGGGTHTCTAAT). The primers used in this work were amplified with both archaeal and bacterial sequences (Frey et al., 2016). PCR fragments were barcoded using Nextera XT Index Kit v2 (Illumina, USA). The PCR fragments were purified using Agencourt AMPure Beads (Beckman Coulter, Brea, CA, USA) and quantitated using Qubit dsDNA HS Assay Kit (Invitrogen, Carlsbad, CA, USA). Then all the amplicons were pooled together in equimolar amounts and sequenced on the Illumina MiSeq instrument $(2 \times 300 \mathrm{nt}$ reads). Paired overlapping reads were merged using FLASH (Magoč and Salzberg, 2011).

\subsection{Bioinformatics analysis}

The pool of 16S rRNA gene sequences was analyzed with QIIME 2 v.2019.10 (https://qiime2.org, Bolyen et al., 2019). DADA2 plugin was used for sequence quality control, denoising, and chimera filtering (Callahan et al., 2016). Operational taxonomic units (OTUs) were clustered applying the VSEARCH plugin (Rognes et al., 2016) with openreference function using the Silva v. 132 database (Glöckner et al., 2017; Quast et al., 2013) with $97 \%$ identity. Taxonomy assignment was performed using BLAST against Silva v. 132 database with $97 \%$ identity. 


\subsection{Nucleotide sequence accession number}

The raw data generated from 16S rRNA gene sequencing were deposited in Sequence Read Archive (SRA) under accession numbers SRR11972844-SRP266728, available via BioProject PRJNA636944.

\section{Results}

\subsection{Net primary production (PP), dissolved organic carbon (DOC), microbial abundance (MA), and dark carbon assimilation (DCA) in the water column}

Phytoplankton primary production (PP) is the main process of carbon fixation in lakes. According to our data, PP in all studied lakes was relatively high (Fig. 2).

While PP values for the surface layers of lakes LK-003, LK-004, and LK-010 were similar (333$468 \mu \mathrm{g} \mathrm{C} \mathrm{L}{ }^{-1} \mathrm{~d}^{-1}$ ), PP in lake LK-002 was considerably higher $\left(723 \mu \mathrm{g} \mathrm{C} \mathrm{L}^{-1} \mathrm{~d}^{-1}\right)$. In shallow lakes photosynthesis rates were high throughout the water column, including the near-bottom horizon; in deep lakes photosynthesis was not detected below $4-5 \mathrm{~m}$. PP calculation for the entire water column (i.e., for the $1 \mathrm{~m}^{2}$ water column; $\mathrm{mg} \mathrm{Cm}^{-2} \mathrm{~d}^{-1}$ ) revealed integral production in deep, mature lakes to be somewhat higher than PP values for shallow lakes (Fig. 2).

DOC concentration in the water column did not vary significantly within each lake $\left( \pm 0.5 \mathrm{mg} \mathrm{CL}^{-1}\right.$; Fig. 3a). Large, deep lakes were characterized by slightly lower DOC (4.5-5.5 $\left.\mathrm{mg} \mathrm{CL}^{-1}\right)$ than small, shallow lakes (7$\left.8 \mathrm{mg} \mathrm{C} \mathrm{L}^{-1}\right)$. Upper horizons of lake sediments had much higher DOC (10-40 $\left.\mathrm{mg} \mathrm{C} \mathrm{L}^{-1}\right)$ and higher variability within the sediment column (Fig. 3b).

Microscopic analysis of the water column samples revealed relatively high microbial abundance (1.7$7.6 \times 10^{6}$ cells $\mathrm{mL}^{-1}$ ), typical of mesotrophic water bodies (Table 2).

Despite the strong wind conditions, which caused mixing of the water masses, MA varied slightly depending on the sampling horizon. In general, it was higher in the surface and near-bottom horizons. Both the highest MA and biomass were revealed in the near-bottom horizon of the shallow thermokarst lake LK-002, while the lowest occurred in the surface horizon of the shallow thermokarst lake LK-010. The average cell volume in the studied samples varied from 0.10 $0.15 \mu \mathrm{m}^{3}$, and the biomass was 220 to $930 \mu \mathrm{g} \mathrm{L}^{-1}$. The share of aggregated cells varied from $1.8 \%-11 \%$. According to our results on total MA, all studied lakes were mesotrophic. However, this assumption is based on the data obtained during the highest seasonal warmth of the water column.

Dark $\mathrm{CO}_{2}$ assimilation (DCA) is an integral characteristic of the activity of chemoautotrophic and chemoheterotrophic microorganisms (Fig. 4).
DCA values in the surface layers of all four lakes were quite similar (14.4-25 $\mu \mathrm{g} \mathrm{CL}^{-1} \mathrm{~d}^{-1}$ ), which follows from their similar hydrological and production characteristics. DCA values in the near-bottom layers varied even less (16.5-

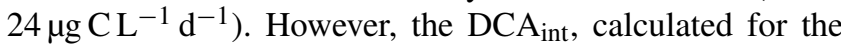
entire depth of the lake, shows that the values of $\mathrm{DCA}_{\text {int }}$ in deep mature lakes are significantly higher than in shallow thermokarst lakes (187-217 $\mathrm{mg} \mathrm{C} \mathrm{m}^{-2} \mathrm{~d}^{-1}$ compared to 24-

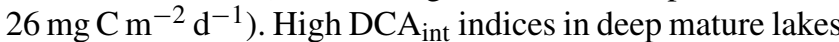
are determined by active heterotrophic processes that take place in all layers of the water column. It follows from the above that the depth of the lakes is an important factor determining the degree of transformation of organic matter in the particulate substance forming bottom sediments.

\subsection{Dissolved methane content $\left[\mathrm{CH}_{4}\right]$ and methane oxidation rate (MO)}

The concentration of dissolved methane measured in the water columns of shallow, well-mixed thermokarst lakes was relatively low (310-480 $\left.\mathrm{nmol} \mathrm{CH}_{4} \mathrm{~L}^{-1}\right)$ with no significant differences between the surface and near-bottom horizons (Fig. 5). In deep mature lakes, methane concentrations decreased significantly (2- to 10-fold) from the near-bottom horizons $\left(4140-975 \mathrm{nmol} \mathrm{CH}_{4} \mathrm{~L}^{-1}\right)$ up to the surface layers (400-420 $\mathrm{nmol} \mathrm{CH}_{4} \mathrm{~L}^{-1}$ ) (Fig. 5).

Experiments with labeled methane revealed that MO rates in the surface layer and near the bottom of the shallow, wellmixed thermokarst lakes were almost the same, although the absolute values of $\mathrm{MO}$ rates in the surface layers of shallow lakes LK-002 and LK-010 differed significantly (3.6 and $16.4 \mathrm{nmol} \mathrm{CH}_{4} \mathrm{~L}^{-1} \mathrm{~d}^{-1}$, respectively) (Fig. 6). In deeper lakes MO rates peaked in the near-bottom horizons: 14.7 and $55.3 \mathrm{nmol} \mathrm{CH}_{4} \mathrm{~L}^{-1} \mathrm{~d}^{-1}$ for lakes LK-004 and LK-003, respectively. MO rates decreased significantly in the upper layers of the water column correlating well with decreasing concentrations of dissolved methane (Figs. 5, 6).

\subsection{Microbial processes of the methane cycle and carbon isotopic composition of methane in the bottom sediments}

Bottom sediments from the bottom surface and to the depth of $14-15 \mathrm{~cm}$ are described in Table 3 .

The sediments of all studied lakes were similar in structure, with a loose, reddish upper horizon (to $3-4 \mathrm{~cm}$ depth), a denser intermediate layer of gray with some reddish interlayers, and a gray, dense lower layer. Numerous gas bubbles were visible in the sediments of lake LK-003. All samples, including the LK-004K thawed ground ice, had pelito-aleuritic texture. Methane content in the sediments varied from $10-1000 \mu \mathrm{mol} \mathrm{CH}_{4} \mathrm{dm}^{-3}$ (Table 3). Rates of hydrogenotrophic (autotrophic) methanogenesis in the upper sediment layer varied within a broad range: from 3-7 to $203 \mathrm{nmol} \mathrm{dm}^{-3} \mathrm{~d}^{-1}$. The highest MG-h rate was observed 
(a) Dissolved organic carbon (DOC) $\mathrm{mg} \mathrm{C} \mathrm{L}^{-1}$
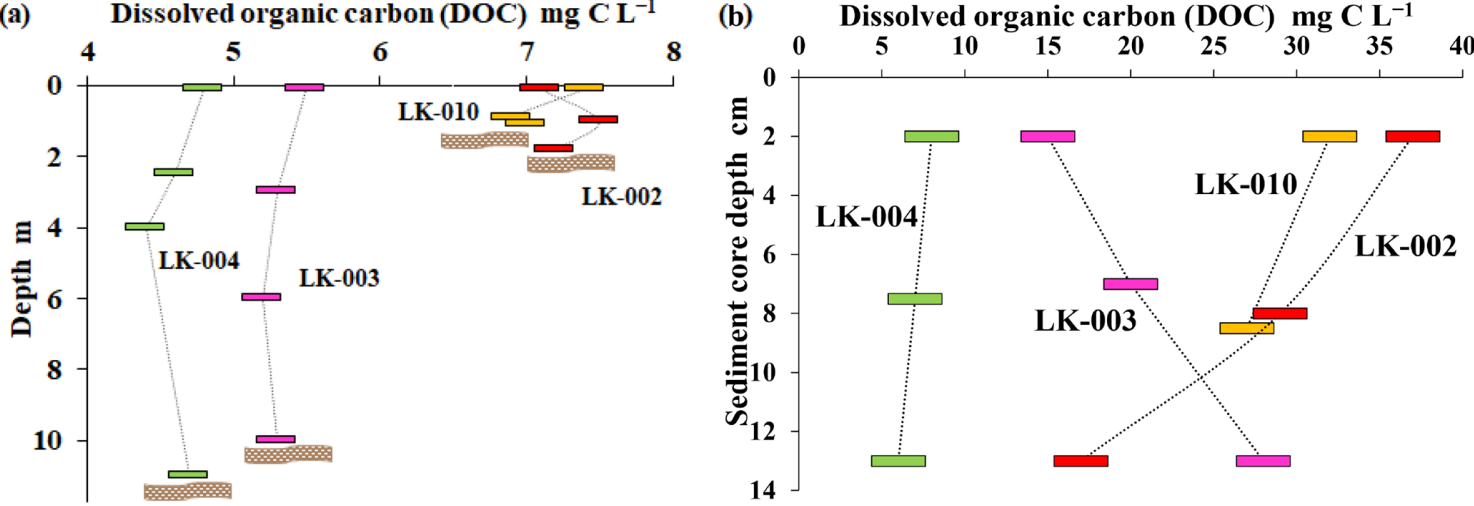

Figure 3. DOC concentration in the water column (a) and pore-water of bottom sediments (b) of four lakes. Location of the bottom is indicated by a brown wavy band.

Table 2. Microbial abundance (MA), cell volume, and biomass $(B)$ in the water column of the studied Yamal lakes.

\begin{tabular}{|c|c|c|c|c|c|}
\hline Lake & Depth (m) & $\begin{array}{r}\text { MA }\left(10^{6}\right. \\
\left.\text { cells mL }{ }^{-1}\right)\end{array}$ & $\begin{array}{r}\text { Cell volume (average) } \\
\qquad\left(\mu \mathrm{m}^{3}\right)\end{array}$ & $\begin{array}{r}B \text { (wet cells) } \\
\left(\mu \mathrm{g} \mathrm{L}^{-1}\right)\end{array}$ & $\begin{array}{r}\text { Aggregated } \\
\text { cells }(\%)\end{array}$ \\
\hline \multirow[t]{2}{*}{ LK-010 } & Surface (w1) & $1.7 \pm 0.2$ & 0.12 & $220 \pm 20$ & 1.8 \\
\hline & $1.0-1.1(\mathrm{w} 2)$ & $2.3 \pm 0.2$ & 0.13 & $300 \pm 20$ & 2.0 \\
\hline \multirow[t]{3}{*}{ LK-002 } & Surface (w1) & $4.6 \pm 0.4$ & 0.15 & $690 \pm 60$ & 11 \\
\hline & $0.9(\mathrm{w} 2)$ & $3.7 \pm 0.3$ & 0.13 & $480 \pm 40$ & 10 \\
\hline & $1.8-1.9(\mathrm{w} 3)$ & $7.6 \pm 0.4$ & 0.15 & $930 \pm 60$ & 13 \\
\hline \multirow[t]{4}{*}{ LK-003 } & Surface (w1) & $3.2 \pm 0.2$ & 0.15 & $520 \pm 40$ & 10 \\
\hline & $2.5(\mathrm{w} 2)$ & $3.3 \pm 0.2$ & 0.14 & $460 \pm 40$ & 8 \\
\hline & $7.0(\mathrm{w} 3)$ & $3.8 \pm 0.3$ & 0.12 & $450 \pm 30$ & 6 \\
\hline & $10.0(\mathrm{w} 4)$ & $4.6 \pm 0.4$ & 0.13 & $690 \pm 50$ & 11 \\
\hline \multirow[t]{3}{*}{ LK-004 } & Surface (w1) & $2.9 \pm 0.2$ & 0.13 & $390 \pm 30$ & 2.1 \\
\hline & $3.0(\mathrm{w} 2)$ & $3.5 \pm 0.3$ & 0.10 & $400 \pm 30$ & 2.0 \\
\hline & 11. (w3) & $4.2 \pm 0.4$ & 0.11 & $490 \pm 40$ & 2.0 \\
\hline
\end{tabular}

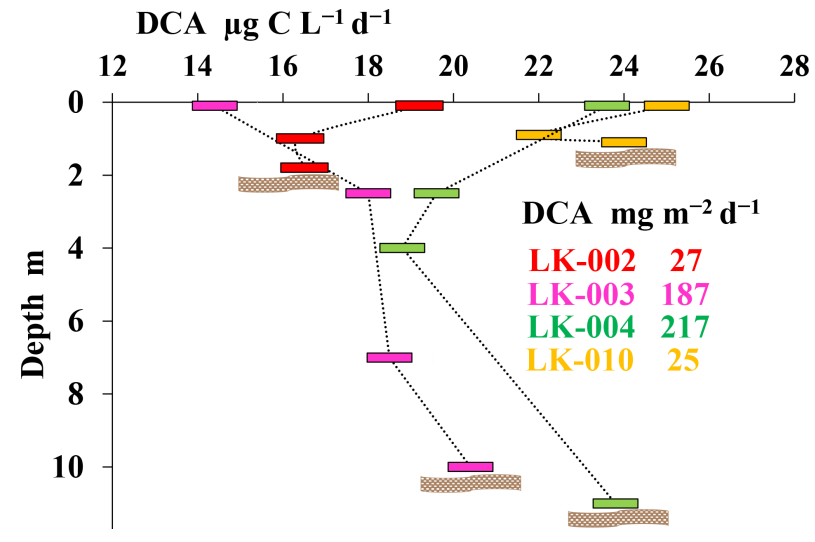

Figure 4. Dark $\mathrm{CO}_{2}$ assimilation (DCA) in four lakes of the Yamal Peninsula (August 2019) in the water horizons $\left(\mu \mathrm{g} \mathrm{C} \mathrm{L}{ }^{-1} \mathrm{~d}^{-1}\right)$ and integral PP for the entire water column $\left(\mathrm{mg} \mathrm{Cm}^{-2} \mathrm{~d}^{-1}\right)$. For all stations, location of the bottom is indicated by a wavy brown band.

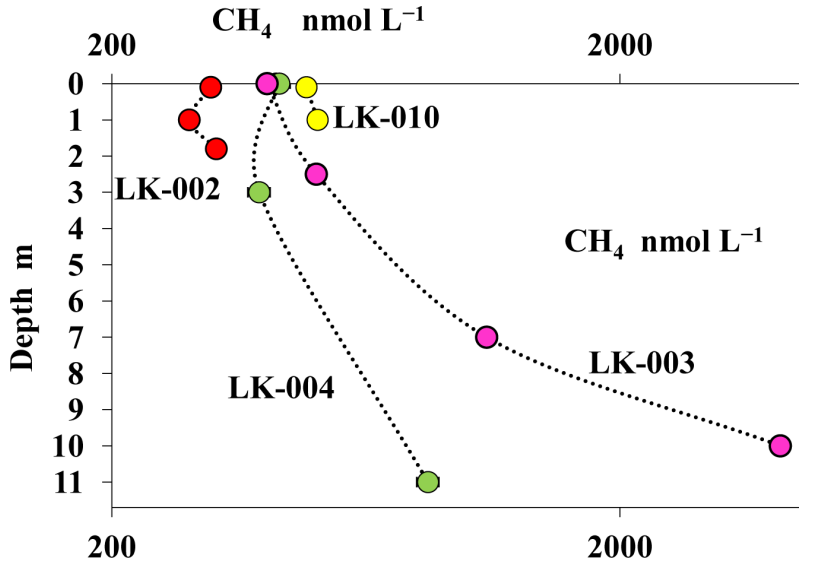

Figure 5. Concentrations of dissolved methane $\left(\mathrm{CH}_{4}, \mathrm{nmol} \mathrm{L}^{-1}\right)$ in the water columns of four Yamal tundra lakes: LK-002 (red), LK010 (yellow), LK-003 (purple), and LK-004 (green). 
Table 3. Methane content, rates of hydrogenotrophic methanogenesis (MG-h) and methane oxidation (MO), and methane carbon isotope composition $\left(\delta^{13} \mathrm{C}-\mathrm{CH}_{4} \%\right.$ o $)$ in the sediments of four Yamal tundra lakes.

\begin{tabular}{lrrrrr}
\hline Lake & $\begin{array}{r}\text { Sediment depth } \\
(\mathrm{cm})\end{array}$ & $\begin{array}{r}\mathrm{CH}_{4} \\
\left(\mu \mathrm{mol} \mathrm{dm}^{-3}\right)\end{array}$ & $\begin{array}{r}\mathrm{MG}-\mathrm{h} \\
\left(\mathrm{nmol} \mathrm{dm}^{-3} \mathrm{~d}^{-1}\right)\end{array}$ & $\begin{array}{r}\mathrm{MO} \\
\left(\mu \mathrm{mol} \mathrm{dm}^{-3} \mathrm{~d}^{-1}\right)\end{array}$ & $\begin{array}{r}\delta^{13} \mathrm{C}_{-} \mathrm{CH}_{4} \\
(\%)\end{array}$ \\
\hline LK-010 & $0-3(\mathrm{~s} 1)$ & 32.8 & $20 \pm 2.0$ & $1.7 \pm 0.2$ & -69.0 \\
& $3-6(\mathrm{~s} 2)$ & 291 & $27 \pm 3.0$ & $5.5 \pm 0.6$ & -69.6 \\
& $6-12(\mathrm{~s} 3)$ & 365 & $10 \pm 1.0$ & $5.6 \pm 0.6$ & -68.2 \\
\hline LK-002 & $0-4(\mathrm{~s} 1)$ & 93.7 & $5.3 \pm 1.1$ & $1.4 \pm 0.2$ & -80.8 \\
& $4-9(\mathrm{~s} 2)$ & 235 & $4.2 \pm 1.0$ & $1.7 \pm 0.2$ & -74.8 \\
& $9-14(\mathrm{~s} 3)$ & 376 & $3.7 \pm 1.0$ & $2.8 \pm 0.3$ & -77.1 \\
\hline LK-003 & $0-3(\mathrm{~s} 1)$ & 594 & $35 \pm 4$ & $4.9 \pm 0.5$ & -64.9 \\
& $3-7(\mathrm{~s} 2)$ & 978 & $67 \pm 7$ & $9.8 \pm 1.0$ & -63.3 \\
& $7-12(\mathrm{~s} 3)$ & 986 & $203 \pm 20$ & $9.9 \pm 1.0$ & -63.5 \\
\hline LK-004 & $0-4(\mathrm{~s} 1)$ & 10.8 & $9.7 \pm 1.0$ & $0.3 \pm 0.03$ & $\mathrm{ND}$ \\
& $4-9(\mathrm{~s} 2)$ & 132 & $29 \pm 3.0$ & $1.3 \pm 0.1$ & -73.4 \\
& $9-15(\mathrm{~s} 3)$ & 407 & $19 \pm 2.0$ & $2.5 \pm 0.3$ & -72.2 \\
LK-004K & $1-6$ & 9.7 & $2.5 \pm 0.4$ & $0.1 \pm 0.01$ & $\mathrm{ND}$ \\
\hline
\end{tabular}

The terms s1, s2, and s3 are designations of the sediment samples. $\mathrm{K}^{*}$ signifies thawed ground ice from the coastal slope of lake LK-004. ND signifies methane content below the analytical threshold.

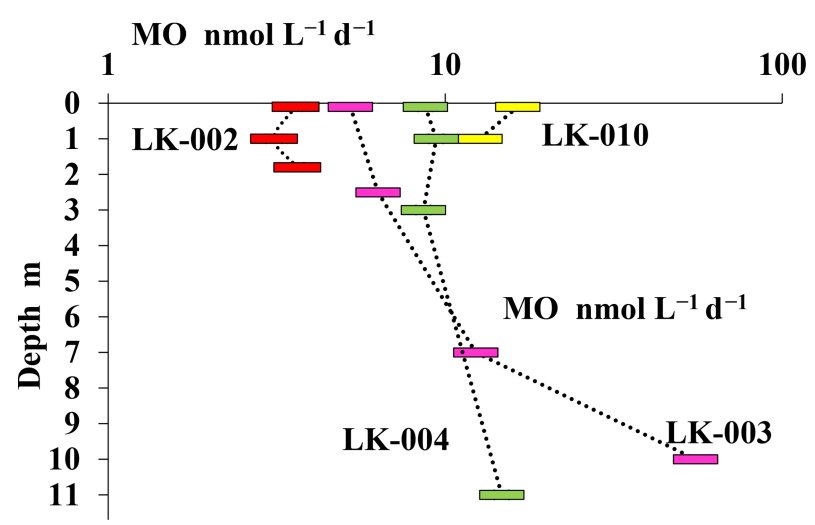

Figure 6. Rates of methane oxidation (nmol $\left.\mathrm{CH}_{4} \mathrm{~L}^{-1} \mathrm{~d}^{-1}\right)$ in the water column of four Yamal tundra lakes: LK-002 (red), LK-010 (yellow), LK-003 (purple), and LK-004 (green).

in the lowermost collected sample from the deep lake LK-003, while the lowest one occurred in the lowermost horizon from the shallow thermokarst lake LK-002. The MO rate (up to $9.9 \mu \mathrm{mol} \mathrm{dm}{ }^{-3} \mathrm{~d}^{-1}$ ) in the sediments exceeded the MG-h rates significantly. MO was more active in the dense subsurface layer than in the loose upper sediment layer. Methane carbon isotope composition $\left(\delta^{13} \mathrm{C}_{-} \mathrm{CH}_{4}\right)$ in the sediments varied from $-80.8 \%$ o to $-63.3 \%$. The highest content of the light carbon isotope $\left({ }^{12} \mathrm{C}\right)$ in methane was observed in lake LK-002. In the sediments of LK003 , methane contained much more heavy carbon $\left({ }^{13} \mathrm{C}\right)$. According to the average values of $\delta^{13} \mathrm{C}_{-} \mathrm{CH}_{4}$, the studied sediments form the following sequence: LK-002 - LK-004 LK-010 - LK-003.

\subsection{Taxonomic composition of microbial communities in the water column and bottom sediments}

An analysis of the 16S rRNA gene sequences from 13 water samples and 13 sediment samples revealed the high taxonomic diversity of microbial communities in all four studied lakes (Fig. 7).

The water column microbial communities of all four lakes were rather similar. Most microorganisms belonged to the Bacteria domain $(99.42 \%-99.95 \%$ of the total read number). Among them, Gammaproteobacteria $(11.4 \%-41.6 \%)$, Actinobacteria $(18.4 \%-30.7 \%)$, Bacteroidetes $(6.2 \%-24.4 \%)$, Verrucomicrobia $(5.4 \%-19.1 \%)$, Alphaproteobacteria ( $4.1 \%-17.3 \%)$, and Betaproteobacteria $(3.2 \%-16.5 \%)$ were the most abundant groups. The share of cyanobacterial OTUs in the surface horizons was 6.7\%-12.4\%. Other bacterial taxa (phyla Acidobacteria, Chloroflexi, Firmicutes, Latescibacteria, Nitrospirae, Patescibacteria, Epsilonproteobacteria, and Deltaproteobacteria) constituted a minor part of the water column microbial communities in all four lakes, with the share of each taxon below $0.5 \%$.

Microbial communities of the bottom sediments differed from those of the water column. Archaea were relatively abundant in the sediments of all four lakes $(20.2 \%-55.6 \%$ of the total number of reads) and were mainly represented by methanogens of the orders Methanomicrobiales, Methanosarcinales, and Methanomassiliicoccales. The upper sediment of lake LK-002 was exceptional in this respect, with the share of archaea not exceeding $3.96 \%$ probably due to contamination of the sample with near-bottom water. This suggestion is supported by the elevated content of 


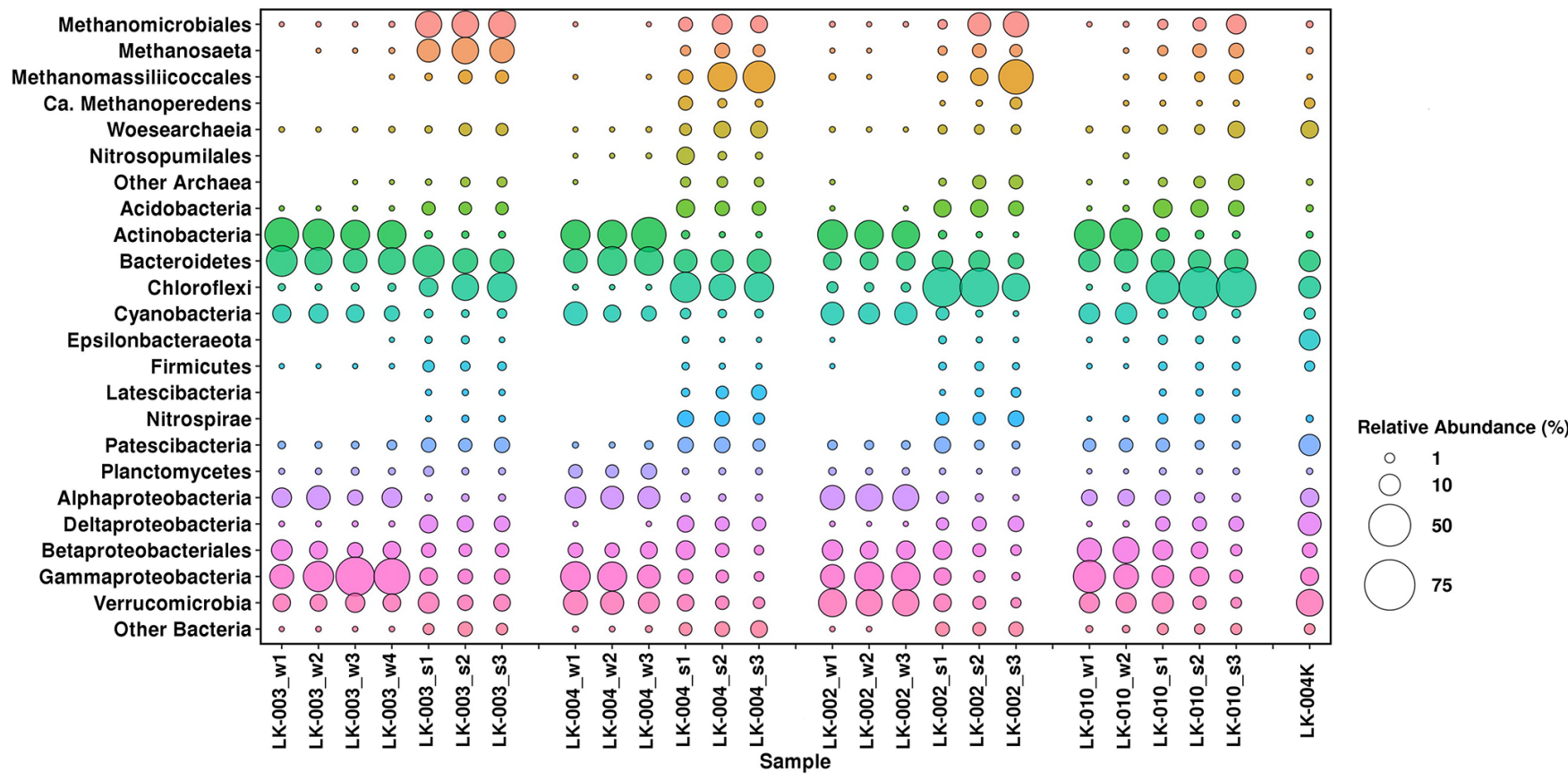

Figure 7. Microbial communities of the water column and bottom sediments in four tundra Lakes of Yamal Peninsula determined by highthroughput sequencing of 16S rRNA genes. On the $x$ axis, " $w$ " and " $s$ " after the sample designation indicate the water and sediment samples, respectively.

cyanobacteria in this sample. Bacteria of the bottom sediments of the studied lakes belonged to the phyla Chloroflexi $(18.5 \%-43.8 \%$ in thermokarst lakes and $6.6 \%-23.2 \%$ in non-thermokarst ones), Bacteroidetes $(4.2 \%-12.6 \%)$, Verrucomicrobia $(1.8 \%-9.0 \%)$, Acidobacteria $(2.3 \%-6.5 \%)$, Gammaproteobacteria $(0.5 \%-8.4 \%)$, Deltaproteobacteria $(2.1 \%-6.1 \%)$, Betaproteobacteria $(3.2 \%-7.2 \%$ in the upper and $0.9 \%-3.2 \%$ in the lower horizons of all lakes), and Nitrospirae (1.7\%-4.8\%) in lakes LK-002 and LK-004. Other bacteria revealed in the sediments, belonging to Actinobacteria, Epsilonbacteraeota, Firmicutes, Latescibacteria, Planctomycetes, and Alphaproteobacteria, constituted less than $1.0 \%$ of the microbial community.

The composition of the community from the thawed permafrost sample (LK-003K) differed significantly from those of the communities of both the water column and the sediments. Only in this sample were the "Ca. Woesearchaeota" OTUs (5.8\%) more numerous than Euryarchaeota OTUs (1.7\%). Members of the phylum Epsilonbacteraeota (genera Arcobacter and Sulfuricurvum) constituted $9.0 \%$, while their abundance in other samples did not exceed $0.65 \%$. The share of Deltaproteobacteria (genera Desulfuromonas and Geopsychrobacter) was $11.6 \%$. Desulfuromonas was not detected in the water column of the studied lakes, and its abundance in the bottom sediments did not exceed $0.81 \%$.

\section{Discussion}

This paper aimed to quantify the microbial processes within the water column and lake sediments of two different types of lakes widely occurring in the Yamal Peninsula: deep mature lakes with established basins and small, shallow lakes. In the first case, the basins likely originated as a result of thermokarst on massive ground ice as the basin was embedded into all geomorphological levels. In the second case, thermokarst on constitutional ground ice might be a starting mechanism for the formation of lake basins. However, other mechanisms responsible for the formation of these lakes are plausible, e.g., the dynamic of the river channel (Romanenko, 1999), gas-emission craters (Dvornikov et al., 2019), and thermo-denudation without the drainage of the excess water.

Microorganisms of the community developing in the water column of tundra lakes during the summer season may be considered as members of four groups: (1) allochthonous permafrost microbiome delivered to the lake with thawed ground ice; (2) autochthonous photosynthetic microorganisms (cyanobacteria and algae detected as algal chloroplasts), with a characteristic brief bloom; (3) heterotrophic (chemoorganotrophic) bacteria consuming dissolved and particulate organic matter; and (4) methanoand methylotrophs, as well as chemolithotrophic bacteria consuming methane and other reduced compounds released from the bottom sediments. 


\subsection{Taxonomic composition of microbial communities in the water column}

The community of the first (allochthonous) group was genetically diverse. It contained heterotrophs of several taxonomic groups which were almost absent in the samples of suspended matter and bottom sediments from all the studied lakes.

The second group (photosynthetic microorganisms) contained cyanobacteria related to the families Nostocaceae and Cyanobiaceae. In the tundra of northern Québec, Canada, phototrophic microorganisms were represented by picocyanobacterial groups Synechococcales and Nostocaceae and the nitrogen-fixing species Dolichospermum curvum (Wacklin et al., 2009), formerly known as Anabaena curva (Crevecoeur et al., 2015). In the deeper parts of Canadian lakes, the relative abundance of the OTUs of anoxygenic green bacteria of the genus Pelodictyon (Chlorobiaceae) was as high as $50 \%$. Our study revealed no Chlorobiaceae in either the shallow thermokarst or deep lakes.

Among heterotrophic bacteria (the third group), the dominant phyla were Actinobacteria (18.4\%-30.7\%) and Bacteroidetes $(6.2 \%-24.4 \%)$, including such species as Actinobacteria " $\mathrm{Ca}$. Planktophila" and " $\mathrm{Ca}$. Nanopelagicus", as well as Flavobacterium succinicans and Sediminibacterium sp. of the phylum Bacteroidetes.

Since tundra lakes are sources of atmospheric methane (Laurion et al., 2010), the composition of the water column methanotrophic community is of special interest. Because of their ability to oxidize methane, aerobic methanotrophs can significantly reduce methane emissions to the atmosphere and thus play an important role in the global methane cycle (Conrad, 1996). Aerobic methanotrophic bacteria belong to three main lineages: Gammaproteobacteria, Alphaproteobacteria, and Verrucomicrobia, with different carbon assimilation pathways (Knief, 2015). In the water column of all studied lakes, methanotrophic microorganisms were far from numerous $(<0.2 \%)$ and belonged exclusively to the order Methylococcales (class Gammaproteobacteria). Most of them belonged to the genus Methylobacter. The bacteria detected in the water samples included members of the genera Methylophilus (methanol-oxidizing bacteria), Acinetobacter (known to perform denitrification coupled with the oxidation of various organic compounds, including humic and fulvic acids) (Wen et al., 2019), and Limnohabitans, as well as " $\mathrm{Ca}$. Methylopumilus turicensis". The latter are methylotrophic planktonic psychrophilic bacteria capable of methanol and methylamine oxidation and preferring the low-temperature conditions of the hypolimnion (Salcher et al., 2015).

\subsection{Taxonomic composition of microbial communities in the bottom sediments}

Gammaproteobacteria of the family Methylomonaceae were found in the sediments of all four lakes (up to $5.2 \%)$. The sequences detected were most closely related to those of Methylobacter tundripaludum of the family Methylomonaceae (Smith and Wrighton, 2019). They were most abundant in the upper sediment layer and could account for the observed methane oxidation. Members of this family can grow under low-oxygen conditions and act as major methane consumers in stratified lakes (Oswald et al., 2017).

An analysis of the published data indicates that members of the families Methylomonaceae and Methylococcaceae predominate in many thermokarst basins (thaw ponds and lakes) in Alaska (de Jong et al., 2018; Matheus Carnevali et al., 2018) and Canada (Crevecoeur et al., 2015, 2017). Methylobacter tundripaludum is a typical component of microbial communities in Arctic bogs and swamped tundra soils (Graef et al., 2011; Liebner et al., 2009; Wartiainen et al., 2006).

A comparison of the data on MO rates and Methylobacter relative abundance indicates that these bacteria probably lay the basis for the microbial community utilizing methane in the sediments of tundra lakes. Methane oxidation can be carried out, apart from aerobic methanotrophic bacteria, by the ANME-2d group archaea assigned to " $\mathrm{Ca}$. Methanoperedens". These archaea may perform anaerobic methane oxidation coupled with the reduction of nitrate (Haroon et al., 2013) or of iron and manganese oxides (Ettwig et al., 2016; Leu et al., 2020). These organisms were detected in the sediments of all lakes except for lake LK003, and in some cases their share was as high as $3 \%$. Thus, during the short warm period of the summer season, in all four tundra lakes, the microbial community of the oxidative branch of the methane cycle contained both aerobic methanotrophic and methylotrophic bacteria and ANME-2d archaea.

In the absence of sulfate ions, methanogenesis is well known to be the terminal stage of $\mathrm{OM}$ degradation in the sediments. Methane formation in tundra lakes (either thermokarst ones or of other types) is known to occur via either the hydrogenotrophic or the acetoclastic pathway; their combination is also possible (de Jong et al., 2018; Matheus Carnevali et al., 2015, 2018). Members of the families Methanosarcinaceae and Methanosaetaceae have been most commonly detected in archaeal methanogenic communities of the bottom sediments of thermokarst ponds. Hydrogenotrophic members of the orders Methanomicrobiales, Methanobacteriales, and Methanocellales were also detected (Matheus Carnevali et al., 2018; Negandhi et al., 2014). The predominance of members of certain taxonomic and physiological groups among the microorganisms of the methane cycle in different horizons of stratified basins has been reported for Lake Pavin, France (Biderre-Petit 
et al., 2019). In this meromictic lake, archaea of the genus Methanoregula predominate in the methanogenic community under anoxic conditions, while methanotrophic bacteria of the genus Methylobacter prevail both in the methanotrophic community of the oxic water column and at the oxic-anoxic interface.

The methanogenic archaeal community in the sediments of the studied Yamal lakes was represented by several OTUs of Methanoregula (order Methanomicrobiales), which constituted up to $16 \%$ of all microorganisms. The abundance of the OTUs of Methanosaeta (order Methanosarcinales) in the sediments of LK-003 was up to $16.9 \%$. The abundance of the OTUs of methylotrophic Euryarchaeota of the order Methanomassiliicoccales (Dridi et al., 2012) was up to $26 \%$ in LK-004 and up to $32 \%$ in LK-002 sediments. Yamal sediments differed significantly in the dominance and the ratio of the major archaeal taxa from those in the sediments of the Emaiksoun thermokarst lake, Utqiagvik, Alaska, where, apart from the OTUs of Methanosaetaceae (30\%$31 \%$ ), high levels of Bathyarchaeota OTUs were revealed (17\%-24\%) (de Jong et al., 2018).

Since only the rate of hydrogenotrophic methanogenesis (MG-h) was determined in the present work, the overall MG rate is most probably an underestimate. This is indirectly indicated by our data on the high abundance of Methanosarcinales and Methanomicrobiales OTUs in the sediments of all four lakes. Members of these lineages are known to be equally capable of both acetoclastic and hydrogenotrophic methanogenesis (Crevecoeur et al., 2016). The contribution of acetoclastic methanogenesis may be rather significant. Thus, in the lake of Rotsee (Switzerland) over $90 \%$ of methane released from the sediment into the water column was produced by acetoclastic Methanosaeta spp., with hydrogenotrophic methanogens responsible only for $7 \%$ (Zepp Falz et al., 1999).

Thus, our calculations estimate the amount of methane produced by archaea via the hydrogenotrophic pathway in the $0-15 \mathrm{~cm}$ sediment layer to be in the range 0.6 to $3.6 \mu \mathrm{mol} \mathrm{CH}_{4} \mathrm{~m}^{-2} \mathrm{~d}^{-1}$ in shallow lakes and 3.5 to $14.5 \mu \mathrm{mol} \mathrm{CH}_{4} \mathrm{~m}^{-2} \mathrm{~d}^{-1}$ in deep mature lakes. The estimated amount of methane oxidized in these sediments is $310-650 \mu \mathrm{mol} \mathrm{CH}_{4} \mathrm{~m}^{-2} \mathrm{~d}^{-1}$ for shallow lakes and 300 $1350 \mu \mathrm{mol} \mathrm{CH}_{4} \mathrm{~m}^{-2} \mathrm{~d}^{-1}$ for deep mature lakes. Based on the above calculations, it may be concluded that the contribution of hydrogenotrophic methanogenesis to the total methane production in the upper sediment layer does not exceed $5 \%$. Thus, our radioisotope studies revealed only a small fraction of methanogenesis occurring in the lakes. Methane is released from the sediments into the water column and is oxidized in the course of its diffusion from the bottom to the lake surface. The estimated amount of methane oxidized in the water column is $7.2-15.5 \mu \mathrm{mol} \mathrm{CH}_{4} \mathrm{~m}^{-2} \mathrm{~d}^{-1}$ for shallow lakes and $120-330 \mu \mathrm{mol} \mathrm{CH}_{4} \mathrm{~m}^{-2} \mathrm{~d}^{-1}$ for deep mature lakes.

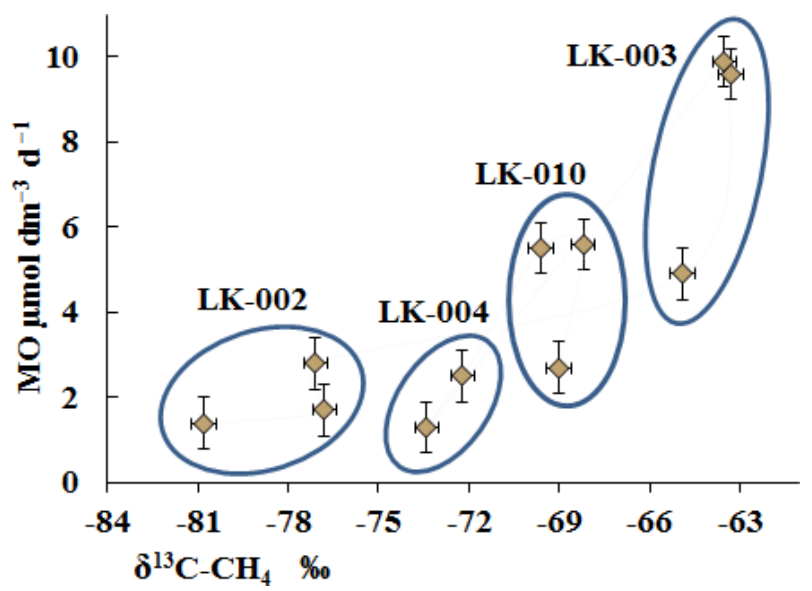

Figure 8. Isotopic composition of methane carbon $\left(\delta^{13} \mathrm{C}-\mathrm{CH}_{4}\right.$ $\%$ ) in the bottom sediments of four Yamal lakes and the rates of methane oxidation ( $\mathrm{MO} ; \mu \mathrm{mol} \mathrm{dm}^{-3} \mathrm{~d}^{-1}$ ).

\subsection{Carbon isotopic composition of methane and methane oxidation rate}

The isotope composition of methane carbon $\left(\delta^{13} \mathrm{C}_{-} \mathrm{CH}_{4}\right)$ in the bottom sediments (Table 3 ) correlated well with the MO rates (Fig. 8).

High MO rates were associated with elevated levels of the heavy carbon isotope (LK-003, three samples), while low MO rates were found in the sediments with a high content of the light carbon isotope (LK-002, three samples) (Fig. 8). The high content of the light carbon isotope in methane from all bottom sediments indicates its biogenic origin. Isotope analysis is, however, unable to differentiate between the modern biogenic methane and methane potentially released from thawing permafrost. MO results in the preferential consumption of the light carbon isotope, with the remaining methane enriched with the heavy isotope; this was especially evident in the case of the LK-003 sediments. At low MO rates, most of the overall methane remains unused, and the resultant methane retains high levels of light carbon (LK002). The low MO rate in the presence of sufficient methane concentrations indicates that the process is limited by some factors other than the substrate deficiency. This is probably the result of a limited supply of oxygen or electron acceptors other than oxygen or the limited supply of biogenic elements.

\subsection{Comparison of the activity of microbial processes in the summer and winter seasons}

Since our study was carried out in the polar summer, during the short season of the high rate of all microbial processes, comparison with the data obtained in April 2018 (Savvichev et al., 2018a) is required to understand the scale of seasonal variations. The data on the rates of microbial processes during the summer and winter seasons are presented in Table 4 
Table 4. Methane concentrations and rates of microbial processes of the methane cycle in the near-bottom water layer and bottom sediments of Yamal lakes in April 2018 (Savvichev et al., 2018a) and August 2019.

\begin{tabular}{lrrrr|rrr}
\hline & \multicolumn{4}{c}{ Bottom sediments (upper layer) } & \multicolumn{3}{c}{ Near-bottom water } \\
\cline { 2 - 8 } & $\begin{array}{r}\mathrm{CH}_{4} \\
\left(\mu \mathrm{mol} \mathrm{dm}^{-3}\right)\end{array}$ & $\begin{array}{r}\mathrm{MG}-\mathrm{h} \\
\left(\mathrm{nmol} \mathrm{dm}^{-3} \mathrm{~d}^{-1}\right)\end{array}$ & $\begin{array}{r}\mathrm{MO} \\
\left(\mu \mathrm{mol} \mathrm{dm}{ }^{-3} \mathrm{~d}^{-1}\right)\end{array}$ & $\begin{array}{r}\delta^{13} \mathrm{C}_{-} \mathrm{CH}_{4} \\
(\%)\end{array}$ & $\begin{array}{r}\mathrm{CH}_{4} \\
\left(\mu \mathrm{mol} \mathrm{L}^{-1}\right)\end{array}$ & $\begin{array}{r}\mathrm{MO} \\
\left(\mathrm{nmol} \mathrm{L}^{-1} \mathrm{~d}^{-1}\right)\end{array}$ & $\begin{array}{r}\delta^{13} \mathrm{C}_{-} \mathrm{CH}_{4} \\
(\% o)\end{array}$ \\
\hline April 2018 & $45-450$ & $2-48$ & $0.05-0.18$ & -89.1 to -80.1 & $3.1-9.1$ & $<2$ & -77.1 to -72.1 \\
August 2019 & $33-990$ & $5-35$ & $2-9.9$ & -80.8 to -64.9 & $0.3-4.1$ & $3.6-55.3$ & -65.6 \\
\hline
\end{tabular}

MO: methane oxidation; MG-h: hydrogenotrophic methanogenesis.
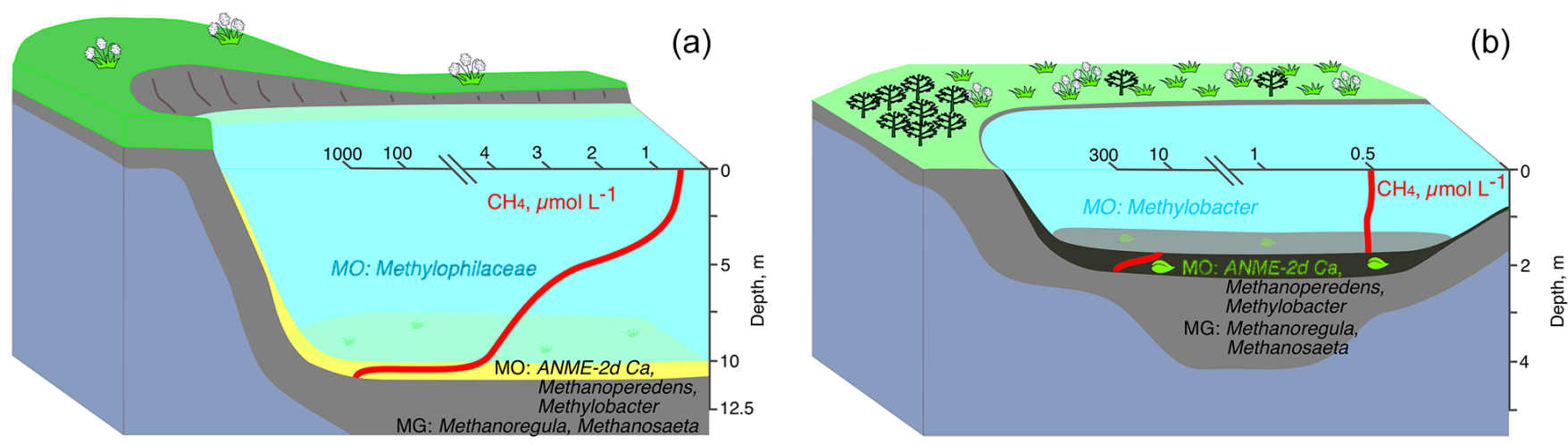

Figure 9. Microbial processes and microbial communities of the methane cycle in the water columns and bottom sediments of deep (a) and shallow tundra lakes (b) of the Yamal Peninsula.

A comparison of these data shows insignificant differences between methane concentrations in the upper sediment layers of Yamal lakes in summer and winter. The differences in the rates of hydrogenotrophic methanogenesis were also insignificant. MO rates were, however, 20-50 times higher in summer. This elevated MO rate resulted in higher levels of ${ }^{13} \mathrm{C}_{-} \mathrm{CH}_{4}\left({ }^{13} \mathrm{C}_{-} \mathrm{CH}_{4}\right.$ to $64.9 \%$ ) in the residual (unconsumed) methane. The methane carbon isotope composition in winter was lighter and more homogeneous. MO rate in the water column was very low in winter, which was caused by the temperature decrease to $0-4{ }^{\circ} \mathrm{C}$ rather than the substrate limitation. The combination of low MO rates in winter and the formation of a thick ice cover resulted in increased methane concentrations in the water column under the ice. The highest seasonal methane concentration in the water column occurs probably immediately before the thawing of the lake ice cover. During the short summer season, phytoplankton production in the Yamal tundra lakes of various depths is relatively high $\left(340-1200 \mathrm{mg} \mathrm{C} \mathrm{m}^{-2} \mathrm{~d}^{-1}\right)$. Allochthonous and autochthonous organic matter partially degrades in the water column and precipitates onto the bottom sediments where methane is the terminal product of anaerobic degradation $\left(90-1000 \mu \mathrm{mol} \mathrm{CH}_{4} \mathrm{dm}^{-3}\right)$.

Our analysis reveals the following scheme of summer microbial processes within the water column and lake sediments of two significantly different lake types: deep mature lakes (with established stable basins) and shallow lakes (resulting from the active thermokarst on constitutional ground ice) (Fig. 9). OM decomposition occurs throughout the year. However, the MO rates in winter are low, which may result in methane accumulation within the water column. During the summer season, the major part of methane in deep mature lakes is oxidized in the water column, and low emission rates from the surface of these lakes may be expected. Most of the area of shallow lakes is frozen to the bottom during winter, and allochthonous OM remains mainly undecomposed. We therefore observed lower rates of methane production in shallow lakes during summer, but since the MO rates were also lower, we expect similar dissolved methane concentrations and methane emissions from the surface of these shallow and deep mature lakes. Given that most of the water within deep lakes remains unfrozen during winter, we might expect that while the annual methane production in these lakes is higher, their water column serves as a microbial filter for methane emission into the atmosphere.

The bottom sediments of tundra lakes are sources of methane which is of biogenic origin according to the data on its carbon isotope composition. The rates of hydrogenotrophic methanogenesis are higher in the sediments of deeper lakes than in the sediments of shallow thermokarst ones. In the sediments of both deep and shallow Yamal lakes, Methanoregula and Methanosaeta 
were predominant components of archaeal methanogenic communities (Fig. 9).

In the sediments of lakes LK-002 and LK-004, the percentage of methylotrophic was significant (OTUs up to $29 \%$ and $14 \%$, respectively). In parallel to methanogenesis, methane oxidation occurs at rather high rates in the sediments of the studied lakes. MO is due to both ANME$2 \mathrm{~d}$ archaea ("Ca. Methanoperedens") and bacteria of the genus Methylobacter (OTUs up to $5.2 \%$ of the total number of reads) (Fig. 9). Methane not consumed in the sediments is released into the water column, where it is oxidized by the community of aerobic methano- and methylotrophic bacteria, in which methylotrophic Betaproteobacteria of the family Methylophilaceae predominate. A decrease in the concentration of dissolved methane from $0.8-4.1 \mu \mathrm{mol} \mathrm{CH}_{4} \mathrm{~L}^{-1}$ in the near-bottom layer to $0.4 \mu \mathrm{mol} \mathrm{CH}_{4} \mathrm{~L}^{-1}$ at the surface is the visible geochemical result of the activity of methanotrophic bacteria in deep lakes (Fig. 9). In shallow lakes wind-mixed to the bottom, methanotrophic bacteria occur in trace amounts, their activity is low, and the geochemical methanotrophic effect is weak. Thus, the depth of a tundra lake is an important factor affecting the scale and completeness of the geochemical processes of the methane cycle caused by microbial activity. The role of the water column as a microbial filter is therefore significant.

\section{Conclusions}

The water column of tundra lakes is a transit zone for the movement of terrigenous and autochthonous organic matter into the bottom sediments. In the sediments, organic matter undergoes a deep microbial transformation resulting in the formation of biogenic methane. Methane is released from the bottom sediments into the water column and flows to the water surface and further into the atmosphere. The microbial community in the water column consumes both organic matter and methane. Lake depth plays a significant role in the completeness of the substrate consumption. During the winter-spring season, sub-ice conditions are characterized by the accumulation of methane in the water column. In the short summer season, its consumption increases sharply. In deep water bodies, the methanotrophic microbial community is a natural filter that prevents methane release into the atmosphere. In shallow thermokarst lakes, the methanotrophic microbial filter is significantly less efficient due to the low thickness of the water layer, as well as wind mixing throughout the entire water column, which accelerates the transport of methane from the bottom to the surface.

Data availability. The raw data generated from 16S rRNA gene sequencing were deposited in Sequence Read Archive (SRA) under the accession numbers SRR11972844-SRP266728, available via BioProject PRJNA636944 (Kadnikov et al., 2020).

Author contributions. The concept was developed by AS and ML. The choice of methodology was done by AS, ML, and YD. The field investigation was carried out by AS, VK, AC, YD, and ArK. The laboratory investigation was performed by AS, IR, EV, VK, $\mathrm{AC}$, and YD. The original draft was written by AS, YD, and AnK. The text was reviewed and edited by AS, ML, AnK, and PS. NP and NR carried out general supervision. NP and ArK were responsible for the project administration.

Competing interests. The authors declare that they have no conflict of interest.

Acknowledgements. The authors thank the "Russian Center for Arctic Exploration" for organizing and supporting the fieldwork and Otto Schmidt Laboratory for providing laboratory facilities. Lake bathymetry, morphological analyses, and DOC measurements in the laboratory were funded by the Russian Foundation for Basic Research, project 18-05-60222, MK-3751.2019.5, and RUDN University Strategic Academic Leadership Program 5-100.

Financial support. Field research and publication of the article have been supported by the Russian Science Foundation (grant no. 16-14-10201). Field sampling was supported by the Russian Foundation for Basic Research (grant nos. 18-05-60222 and MK3751.2019.5). Radiotracer studies were supported by the Russian Foundation for Basic Research, project 20-04-00487. Investigation of the processes of the methane cycle and of the microbial community structure was supported by the Ministry of Science and Higher Education of the Russian Federation.

Review statement. This paper was edited by Sébastien Fontaine and reviewed by June Skeeter and one anonymous referee.

\section{References}

Arctic and Antarctic Research Institute: Yamal-Gydan area, edited by: Sisko R. K., Gidrometeoizdat, Saint-Petersburg, 1977.

Auman, A. J., Stolyar, S., Costello, A. M., and Lidstrom, M. E.: Molecular characterization of methanotrophic isolates from freshwater lake sediment, Appl. Environ. Microbiol., 66, 5259-5266, https://doi.org/10.1128/AEM.66.12.52595266.2000, 2000.

Bastviken, D., Cole, J. J., Pace, M. L., and Tranvik, L. J.: Methane emissions from lakes: Dependence of lake characteristics, two regional assessments, and a global estimate, Global Biogeochem. Cy., 18, GB4009, https://doi.org/10.1029/2004GB002238, 2004

Biderre-Petit, C., Taib, N., Gardon, H., Hochart, C., and Debroas, D.: New insights into the pelagic microorganisms involved in the methane cycle in the meromictic Lake Pavin 
through metagenomics, FEMS Microbiol. Ecol., 95, 1-14, https://doi.org/10.1093/femsec/fiy183, 2019.

Biskaborn, B. K., Smith, S. L., Noetzli, J., Matthes, H., Vieira, G., Streletskiy, D. A., Schoeneich, P., Romanovsky, V. E., Lewkowicz, A. G., Abramov, A. A., Allard, M., Boike, J., Cable, W. L., Christiansen, H. H., Delaloye, R., Diekmann, B., Drozdov, D. S., Etzelmüller, B., Grosse, G., Guglielmin, M., Ingeman-Nielsen, T., Isaksen, K., Ishikawa, M., Johansson, M., Johannsson, H., Joo, A., Kaverin, D. A., Kholodov, A. L., Konstantinov, P. Y., Kröger, T., Lambiel, C., Lanckman, J. P., Luo, D., Malkova, G. V., Meiklejohn, I., Moskalenko, N. G., Oliva, M., Phillips, M., Ramos, M., Sannel, A. B. K., Sergeev, D. O., Seybold, C., Skryabin, P. N., Vasiliev, A. A., Wu, Q., Yoshikawa, K., Zheleznyak, M., and Lantuit, H.: Permafrost is warming at a global scale, Nat. Commun., 10, 111, https://doi.org/10.1038/s41467-018-08240-4, 2019.

Bolyen, E., Rideout, J. R., Dillon, M. R., Bokulich, N. A., Abnet, C. C., Al-Ghalith, G. A., Alexander, H., Alm, E. J., Arumugam, M., Asnicar, F., Bai, Y., Bisanz, J. E., Bittinger, K., Brejnrod, A., Brislawn, C. J., Brown, C. T., Callahan, B. J., CaraballoRodriguez, A. M., Chase, J., Cope, E. K., Da Silva, R., Diener, C., Dorrestein, P. C., Douglas, G. M., Durall, D. M., Duvallet, C., Edwardson, C. F., Ernst, M., Estaki, M., Fouquier, J., Gauglitz, J. M., Gibbons, S. M., Gibson, D. L., Gonzalez, A., Gorlick, K., Guo, J., Hillmann, B., Holmes, S., Holste, H., Huttenhower, C., Huttley, G. A., Janssen, S., Jarmusch, A. K., Jiang, L., Kaehler, B. D., Kang, K. B., Keefe, C. R., Keim, P., Kelley, S. T., Knights, D., Koester, I., Kosciolek, T., Kreps, J., Langille, M. G. I., Lee, J., Ley, R., Liu, Y. X., Loftfield. E., Lozupone, C., Maher, M., Marotz, C., Martin, B. D., McDonald, D., McIver, L. J., Melnik, A. V., Metcalf, J. L., Morgan, S. C., Morton, J. T., Naimey, A. T., Navas-Molina, J. A., Nothias, L. F., Orchanian, S. B., Pearson, T., Peoples, S. L., Petras, D., Preuss, M. L., Pruesse, E., Rasmussen, L. B., Rivers, A., Robeson, M. S., Rosenthal, P., Segata, N., Shaffer, M., Shiffer, A., Sinha, R., Song, S. J., Spear, J. R., Swafford, A. D., Thompson. L.R., Torres, P. J., Trinh, P., Tripathi, A., Turnbaugh, P. J., Ul-Hasan, S., van der Hooft, J. J. J., Vargas, F., Vazquez-Baeza, Y., Vogtmann, E., von Hippel, M., Walters, W., Wan, Y., Wang, M., Warren, J., Weber, K. C., Williamson, C. H. D., Willis, A. D., Xu, Z. Z., Zaneveld. J. R., Zhang, Y., Zhu, Q., Knight, R., and Caporaso, J. G.: Reproducible, interactive, scalable and extensible microbiome data science using QIIME 2, Nat. Biotechnol., 37, 852-857, https://doi.org/10.1038/s41587-019-0209-9, 2019.

Brown, J., Ferrians, J. O. J., Heginbottom, J. A., and Melnikov, E. S.: Circum-Arctic Map of Permafrost and Ground-Ice Conditions, scale $1: 10000000$, Version 2, NSIDC: National Snow and Ice Data Center, Boulder, 2002.

Callahan, B. J., McMurdie, P. J., Rosen, M. J., Han, A. W., Johnson, A. J. A., and Holmes, S. P.: DADA2: High-resolution sample inference from Illumina amplicon data, Nat. Method., 13, 581583, https://doi.org/10.1038/nmeth.3869, 2016.

Cole, J. J., Caraco, N. F., Kling, G. W., and Kratz, T. K.: Carbon dioxide supersaturation in the surface waters of lakes, Science, 265, 1568-1570, https://doi.org/10.1126/science.265.5178.1568, 1994.

Colin Murrell, J. and Jetten, M. S. M.: The microbial methane cycle, Environ. Microbiol. Rep., 1, 279-284, https://doi.org/10.1111/j.1758-2229.2009.00089.x, 2009.
Conrad, R.: Soil Microorganisms as Controllers of Atmospheric Trace Gases $\left(\mathrm{H}_{2}, \mathrm{CO}, \mathrm{CH}_{4}, \mathrm{OCS}, \mathrm{N}_{2} \mathrm{O}\right.$, and $\left.\mathrm{NO}\right)$, Microbiol. Rev., 60, 609-640, https://doi.org/10.1007/978-3-642-610967_11, 1996.

Craig, H.: The natural distribution of radiocarbon and the exchange time of carbon dioxide between atmosphere and sea, Tellus, 9, 1-17, 1957.

Crevecoeur, S., Vincent, W. F., Comte, J., and Lovejoy, C.: Bacterial community structure across environmental gradients in permafrost thaw ponds: methanotroph-rich ecosystems, Front. Microbiol., 6, 192, https://doi.org/10.3389/fmicb.2015.00192, 2015.

Crevecoeur, S., Vincent, W. F., and Lovejoy, C.: Environmental selection of planktonic methanogens in permafrost thaw ponds, Sci. Rep., 6, 31312, https://doi.org/10.1038/srep31312, 2016.

Crevecoeur, S., Vincent, W. F., Comte, J., Matveev, A., and Lovejoy, C.: Diversity and potential activity of methanotrophs in high methane-emitting permafrost thaw ponds, edited by: Zhou, Z., PLoS One, 12, e0188223, https://doi.org/10.1371/journal.pone.0188223, 2017.

de Jong, A. E. E., Zandt, M. H., Meisel, O. H., Jetten, M. S. M., Dean, J. F., Rasigraf, O., and Welte, C. U.: Increases in temperature and nutrient availability positively affect methane-cycling microorganisms in Arctic thermokarst lake sediments, Environ. Microbiol., 20, 4314-4327, https://doi.org/10.1111/14622920.14345, 2018.

Dostovalov, B. N. and Kudryavtsev, V. A.: General permafrost, MSU, Moscow, 1967.

Dridi, B., Fardeau, M. L., Ollivier, B., Raoult, D., and Drancourt, M.: Methanomassiliicoccus luminyensis gen. nov., sp. nov., a methanogenic archaeon isolated from human faeces, Int. J. Syst. Evol. Microbiol., 62, 1902-1907, https://doi.org/10.1099/ijs.0.033712-0, 2012.

Dubikov, G. I.: Paragenesis of massive ground ice and frozen rocks of Western Siberia, in Massive ground ice of the permafrost zone, MPI SB RAS, Yakutsk, 24-42, 1982.

Dvornikov, Y. A., Leibman, M. O., Heim, B., Bartsch, A., Haas, A., Khomutov, A. V., Gubarkov, A. A., Mikhaylova, M., Mullanurov, D. R., Widhalm, B., Skorospekhova, T. V., and Fedorova, I. V.: Geodatabase and WebGIS project for long-term permafrost monitoring at the Vaskiny Dachi Research Station, Yamal, Russia, Polarforschung, 85, 107-115, https://doi.org/10.2312/polfor.2016.007, 2016.

Dvornikov, Y. A., Leibman, M. O., Heim, B., Bartsch, A., Herzschuh, U., Skorospekhova, T. V., Fedorova, I. V., Khomutov, A. V., Widhalm, B., Gubarkov, A. A., and Rößler, S.: Terrestrial CDOM in lakes of Yamal Peninsula: Connection to lake and lake catchment properties, Remote Sens., 10, 167, https://doi.org/10.3390/rs10020167, 2018.

Dvornikov, Y. A., Leibman, M. O., Khomutov, A. V., Kizyakov, A. I., Semenov, P. B., Bussmann, I., Babkin, E. M., Heim, B., Portnov, A., Babkina, E. A., Streletskaya, I. D., Chetverova, A. A., Kozachek, A. V., and Meyer, H.: Gasemission craters of the Yamal and Gydan peninsulas: A proposed mechanism for lake genesis and development of permafrost landscapes, Permafr. Periglac. Process., 30, 146-162, https://doi.org/10.1002/ppp.2014, 2019.

Edelstein, K. K., Alabyan, A. M., Gorin, S. L., and Popryadukhin, A. A.: Hydrological and Hydrochemical Features of the Largest 
Lakes of the Yamal Peninsula, Proc. Karelian Res. Cent. Russ. Acad. Sci., 10, 3-16, https://doi.org/10.17076/lim571, 2017.

Ettwig, K. F., Zhu, B., Speth, D., Keltjens, J. T., Jetten, M. S. M., and Kartal, B.: Archaea catalyze iron-dependent anaerobic oxidation of methane, P. Natl. Acad. Sci. USA, 113, 12792 12796, https://doi.org/10.1073/pnas.1609534113, 2016.

Fotiev, S. M.: The regularities in the formation of natural waters of ionic-salt composition, Yamal peninsula, Earth's Cryosph., 3, 40-65, 1999.

Frey, B., Rime, T., Phillips, M., Stierli, B., Hajdas, I., Widmer, F., and Hartmann, M.: Microbial diversity in European alpine permafrost and active layers, FEMS Microbiol. Ecol., 92, fiw018, https://doi.org/10.1093/femsec/fiw018, 2016.

Glöckner, F. O., Yilmaz, P., Quast, C., Gerken, J., Beccati, A., Ciuprina, A., Bruns, G., Yarza, P., Peplies, J., Westram, R., and Ludwig, W.: 25 years of serving the community with ribosomal RNA gene reference databases and tools, J. Biotechnol., 261, 169-176, https://doi.org/10.1016/j.jbiotec.2017.06.1198, 2017.

Graef, C., Hestnes, A. G., Svenning, M. M., and Frenzel, P.: The active methanotrophic community in a wetland from the High Arctic, Environ. Microbiol. Rep., 3, 466-472, https://doi.org/10.1111/j.1758-2229.2010.00237.x, 2011.

Grosse, G., Jones, B., and Arp, C.: Thermokarst Lakes, Drainage, and Drained Basins, in Treatise on Geomorphology, vol. 8, edited by: Shroder, J., Giardino, R., and Harbor, J., Academic Press, San-Diego, 325-353, 2013.

Hamdan, L. J., Gillevet, P. M., Pohlman, J. W., Sikaroodi, M., Greinert, J., and Coffin, R. B.: Diversity and biogeochemical structuring of bacterial communities across the Porangahau ridge accretionary prism, New Zealand, FEMS Microbiol. Ecol., 77, 518-532, https://doi.org/10.1111/j.1574-6941.2011.01133.x, 2011.

Haroon, M. F., Hu, S., Shi, Y., Imelfort, M., Keller, J., Hugenholtz, P., Yuan, Z., and Tyson, G. W.: Anaerobic oxidation of methane coupled to nitrate reduction in a novel archaeal lineage, Nature, 500, 567-570, https://doi.org/10.1038/nature12375, 2013.

Heslop, J. K., Walter Anthony, K. M., Sepulveda-Jauregui, A., Martinez-Cruz, K., Bondurant, A., Grosse, G., and Jones, M. C.: Thermokarst lake methanogenesis along a complete talik profile, Biogeosciences, 12, 4317-4331, https://doi.org/10.5194/bg-124317-2015, 2015

Heuer, V. B., Pohlman, J. W., Torres, M. E., Elvert, M., and Hinrichs, K.-U.: The stable carbon isotope biogeochemistry of acetate and other dissolved carbon species in deep subseafloor sediments at the northern Cascadia Margin, Geochim. Cosmochim. Ac., 73, 3323-3336, https://doi.org/10.1016/J.GCA.2009.03.001, 2009.

Hobbie, J. E., Daley, R. J., and Jasper, S.: Use of nuclepore filters for counting bacteria by fluorescence microscopy, Appl. Environ. Microbiol., 33, 1225-1228, https://doi.org/10.1128/aem.33.5.1225-1228.1977, 1977.

IPCC: Climate Change 2014: Synthesis Report, Geneva, 2014.

Kachurin, S. P.: Thermokarst on the USSR territory, edited by: Melnikova, N. B., Academy of Sciences USSR, Moscow, 1961.

Kadnikov, V. V., Mardanov, A. V., and Ravin, N. V.: Sequencing Read Archive data set, BioProject accession no., PRJNA636944, The water column of the Yamal tundra lakes as a microbial filter preventing methane emission, available at: https://www.
ncbi.nlm.nih.gov/bioproject/PRJNA636944, last access: 10 June 2020 .

Kizyakov, A. I. and Leibman, M. O.: Cryogenic relief-formation processes: A review of 2010-2015 publications, Earth's Cryosph., 20, 40-52, https://doi.org/10.21782/KZ1560-74962016-4(45-58), 2016

Knief, C.: Diversity and habitat preferences of cultivated and uncultivated aerobic methanotrophic bacteria evaluated based on pmoA as molecular marker, Front. Microbiol., 6, 1346, https://doi.org/10.3389/fmicb.2015.01346, 2015.

Kravtsova, V. I. and Rodionova, T. V.: Investigation of the dynamics in area and number of thermokarst lakes in various regions of Russian cryolithozone using satellite images, Earth's Cryosph., 20, 81-89, 2016.

Kritsuk, L. N.: Ground ice of West Siberia, edited by: Tolstikhin, O N., Nauchniy Mir, Moscow, 2010.

Laurion, I., Vincent, W. F., MacIntyre, S., Retamal, L., Dupont, C., Francus, P., and Pienitz, R.: Variability in greenhouse gas emissions from permafrost thaw ponds, Limnol. Oceanogr., 55, 115-133, https://doi.org/10.4319/lo.2010.55.1.0115, 2010.

Leibman, M. O., Kizyakov, A. I., Plekhanov, A. V., and Streletskaya, I. D.: New permafrost feature - deep crater in Central Yamal (West Siberia, Russia) as a response to local climate fluctuations, Geogr. Environ. Sustain., 7, 68-79, https://doi.org/10.24057/2071-9388-2014-7-4-68-79, 2014.

Leu, A. O., Cai, C., McIlroy, S. J., Southam, G., Orphan, V. J., Yuan, Z., Hu, S., and Tyson, G. W.: Anaerobic methane oxidation coupled to manganese reduction by members of the Methanoperedenaceae, ISME J., 14, 1030-1041, https://doi.org/10.1038/s41396-020-0590-x, 2020.

Liebner, S., Rublack, K., Stuehrmann, T., and Wagner, D.: Diversity of aerobic methanotrophic bacteria in a permafrost active layer soil of the Lena Delta, Siberia, Microb. Ecol., 57, 25-35, https://doi.org/10.1007/s00248-008-9411-x, 2009.

Magoč, T. and Salzberg, S. L.: FLASH: Fast length adjustment of short reads to improve genome assemblies, Bioinformatics, 27, 2957-2963, https://doi.org/10.1093/bioinformatics/btr507, 2011.

Marsh, P., Russell, M., Pohl, S., Haywood, H., and Onclin, C.: Changes in thaw lake drainage in the Western Canadian Arctic from 1950 to 2000, Hydrol. Process., 23, 145-158, https://doi.org/10.1002/hyp.7179, 2009.

Martinez-Cruz, K., Sepulveda-Jauregui, A., Walter Anthony, K. M., and Thalasso, F.: Geographic and seasonal variation of dissolved methane and aerobic methane oxidation in Alaskan lakes, Biogeosciences, 12, 4595-4606, https://doi.org/10.5194/bg-124595-2015, 2015.

Matheus Carnevali, P. B., Rohrssen, M., Williams, M. R., Michaud, A. B., Adams, H., Berisford, D., Love, G. D., Priscu, J. C., Rassuchine, O., Hand, K. P., and Murray, A. E.: Methane sources in arctic thermokarst lake sediments on the North Slope of Alaska, Geobiology, 13, 181-197, https://doi.org/10.1111/gbi.12124, 2015.

Matheus Carnevali, P. B., Herbold, C. W., Hand, K. P., Priscu, J. C., and Murray, A. E.: Distinct Microbial Assemblage Structure and Archaeal Diversity in Sediments of Arctic Thermokarst Lakes Differing in Methane Sources, Front. Microbiol., 9, 1192, https://doi.org/10.3389/fmicb.2018.01192, 2018. 
McAuliffe, C.: Gas chromatographic determination of solutes by multiple phase equilibrium, Chemical Technology, 1, 46-51, 1971.

Negandhi, K., Laurion, I., and Lovejoy, C.: Bacterial communities and greenhouse gas emissions of shallow ponds in the High Arctic, Polar Biol., 37, 1669-1683, https://doi.org/10.1007/s00300014-1555-1, 2014.

Oswald, K., Graf, J. S., Littmann, S., Tienken, D., Brand, A., Wehrli, B., Albertsen, M., Daims, H., Wagner, M., Kuypers, M. M. M., Schubert, C. J., and Milucka, J.: Crenothrix are major methane consumers in stratified lakes, ISME J., 11, 2124-2140, https://doi.org/10.1038/ismej.2017.77, 2017.

Patova, E. N.: Bloom-Forming Cyanoprokaryotes in Kharbeyskie Lakes of Bolshezemelskaya Tundra, J. Sib. Fed. Univ. Biol., 7, 282-290, 2014.

Pimenov, N. V. and Bonch-Osmolovskaya, E. A.: 2 In Situ Activity Studies in Thermal Environments, Academic Press, Method. Microbiol., 35, 29-53, 2006.

Pokrovskiy, O. S., Shirokova, L. S., and Kirpotin, S. N.: Microbiological factors controlling carbon cycle in thermokarst water bodies of Western Siberia, Tomsk State Univ. J. Biol., 3, 199-217, 2012.

Polishchuk, Y. M., Bogdanov, A. N., Muratov, I. N., Polishchuk, V. Y., Lim, A. G., Manasypov, R. M., Shirokova, L. S., and Pokrovsky, O. S.: Minor contribution of small thaw ponds to the pools of carbon and methane in the inland waters of the permafrost-affected part of the Western Siberian Lowland, Environ. Res. Lett., 13, 045002, https://doi.org/10.1088/17489326/aab046, 2018.

Quast, C., Pruesse, E., Yilmaz, P., Gerken, J., Schweer, T., Yarza, P., Peplies, J., and Glöckner, F. O.: The SILVA ribosomal RNA gene database project: improved data processing and web-based tools, Nucleic. Acids Res., 41, 590-596, https://doi.org/10.1093/nar/gks1219, 2013.

Rognes, T., Flouri, T., Nichols, B., Quince, C., and Mahé, F.: VSEARCH: A versatile open source tool for metagenomics, Peer J., 4, e2584, https://doi.org/10.7717/peerj.2584, 2016.

Romanenko, F. A.: Dynamic of lake basins, in: Processes of erosion on Central Yamal, edited by: Sidorchuk, A. Y. and Baranov, A.V., Gomel CNTDI, Saint-Petersburg, 139-160, 1999.

Romanovskii, N. N.: Fundamentals of lithosphere cryogenesis, edited by: Baulin, V. V., MSU, Moscow, 1993.

Salcher, M. M., Neuenschwander, S. M., Posch, T., and Pernthaler, J.: The ecology of pelagic freshwater methylotrophs assessed by a high-resolution monitoring and isolation campaign, ISME J., 9, 2442-2453, https://doi.org/10.1038/ismej.2015.55, 2015.

Sassen, R. and Macdonald, I. R.: Hydrocarbons of experimental and natural gas hydrates, Gulf of Mexico continental slope, Org. Geochem., 26, 289-293, https://doi.org/10.1016/S01466380(97)00001-6, 1997.

Savvichev, A. S., Leibman, M. O., Kadnikov, V., Kallistova, A., Pimenov, N. V., Ravin, N., Dvornikov, Y. A., and Khomutov, A. V.: Microbiological study of Yamal lakes: a key to understanding the evolution of gas emission craters, Geosciences, 8, 478, https://doi.org/10.3390/geosciences8120478, 2018a.

Savvichev, A. S., Babenko, V. V., Lunina, O. N., Letarova, M. A., Boldyreva, D. I., Weslopolova, E. F., Demidenko, N. A., Kokryatskaya, N. M., Krasnova, E. D., Gaysin, V. A., Kostryukova, E. S., Gorlenko, V. M., and Letarov, A. V.: Sharp water column stratification with an extremely dense microbial population in a small meromictic lake Trekhtzetnoe separated from the White Sea, Environ. Microbiol., 20, 3784-3797, https://doi.org/10.1111/1462-2920.14384, 2018b.

Sepulveda-Jauregui, A., Walter Anthony, K. M., MartinezCruz, K., Greene, S., and Thalasso, F.: Methane and carbon dioxide emissions from 40 lakes along a north-south latitudinal transect in Alaska, Biogeosciences, 12, 3197-3223, https://doi.org/10.5194/bg-12-3197-2015, 2015.

Serikova, S., Pokrovsky, O. S., Laudon, H., Kritzkov, I. V., Lim, A. G., Manasypov, R. M., and Karlsson, J.: High carbon emissions from thermokarst lakes of Western Siberia, Nat. Commun., 10, 1552, https://doi.org/10.1038/s41467-019-09592-1, 2019.

Singleton, C. M., McCalley, C. K., Woodcroft, B. J., Boyd, J. A., Evans, P. N., Hodgkins, S. B., Chanton, J. P., Frolking, S., Crill, P. M., Saleska, S. R., Rich, V. I., and Tyson, G. W.: Methanotrophy across a natural permafrost thaw environment, ISME J., 12, 2544-2558, https://doi.org/10.1038/s41396-018-0065-5, 2018.

Smith, G. J. and Wrighton, K. C.: Metagenomic Approaches Unearth Methanotroph Phylogenetic and Metabolic Diversity, Curr. Issues Mol. Biol., 33, 57-84, https://doi.org/10.21775/cimb.033.057, 2019.

Smith, S. L., Sheng, Y., MacDonald, G. M., and Hinzman, L. D.: Disappearing Arctic Lakes, Science, 308, 1429, https://doi.org/10.1126/science.1108142, 2005.

Townsend-Small, A., Åkerström, F., Arp, C. D., and Hinkel, K. M.: Spatial and Temporal Variation in Methane Concentrations, Fluxes, and Sources in Lakes in Arctic Alaska, J. Geophys. Res.-Biogeo., 122, 2966-2981, https://doi.org/10.1002/2017JG004002, 2017.

Vonk, J. E., Tank, S. E., Bowden, W. B., Laurion, I., Vincent, W. F., Alekseychik, P., Amyot, M., Billet, M. F., Canário, J., Cory, R. M., Deshpande, B. N., Helbig, M., Jammet, M., Karlsson, J., Larouche, J., MacMillan, G., Rautio, M., Walter Anthony, K. M., and Wickland, K. P.: Reviews and syntheses: Effects of permafrost thaw on Arctic aquatic ecosystems, Biogeosciences, 12, 7129-7167, https://doi.org/10.5194/bg-12-7129-2015, 2015.

Wacklin, P., Hoffmann, L., and Komárek, J.: Nomenclatural validation of the genetically revised cyanobacterial genus Dolichospermum (Ralfs ex Bornet et Flahault) comb. nov., Fottea, 9, 59-64, 2009.

Walter Anthony, K. M., Zimov, S. A., Chanton, J. P., Verbyla, D., and Chapin, F. S. I.: Methane bubbling from Siberian thaw lakes as a positive feedback to climate warming, Nature, 443, 71-75, https://doi.org/10.1038/nature05040, 2006.

Walter Anthony, K. M., Smith, L. C., and Chapin, F. S. I.: Methane bubbling from northern lakes: Present and future contributions to the global methane budget, Philos. T. R. Soc. A, 365, 1657-1676, https://doi.org/10.1098/rsta.2007.2036, 2007.

Wartiainen, I., Hestnes, A. G., McDonald, I. R., and Svenning, M. M.: Methylobacter tundripaludum sp. nov., a methane-oxidizing bacterium from Arctic wetland soil on the Svalbard islands, Norway $\left(78^{\circ} \mathrm{N}\right)$, Int. J. Syst. Evol. Microbiol., 56, 109-113, https://doi.org/10.1099/ijs.0.63728-0, 2006.

Wen, G., Wang, T., Li, K., Wang, H., Wang, J., and Huang, T.: Aerobic denitrification performance of strain Acinetobacter johnsonii WGX-9 using different natural organic matter as carbon source: Effect of molecular weight, Water Res., 164, 114956, https://doi.org/10.1016/j.watres.2019.114956, 2019. 
Wik, M., Varner, R. K., Walter Anthony, K. M., MacIntyre, S., and Bastviken, D.: Climate-sensitive northern lakes and ponds are critical components of methane release, Nat. Geosci., 9, 99-105, https://doi.org/10.1038/ngeo2578, 2016.

Xu, X., Yuan, F., Hanson, P. J., Wullschleger, S. D., Thornton, P. E., Riley, W. J., Song, X., Graham, D. E., Song, C., and Tian, H.: Reviews and syntheses: Four decades of modeling methane cycling in terrestrial ecosystems, Biogeosciences, 13, 3735-3755, https://doi.org/10.5194/bg-13-3735-2016, 2016.
Zepp Falz, K., Holliger, C., Großkopf, R., Liesack, W. Nozhevnikova, A. N., Müller, B., Wehrli, B., and Hahn, D.: Vertical distribution of methanogens in the anoxic sediment of Rotsee (Switzerland), Appl. Environ. Microbiol., 65, 2402-2408, https://doi.org/10.1128/aem.65.6.2402-2408.1999, 1999. 